Portland State University

PDXScholar

\title{
A Present-Situation Analysis and Needs Assessment of Latinx Workers in the Portland Fast-Food Industry: a Study of their Employment Journeys \& Job-Related Language Needs
}

Livia Z. Lichtenstein-Hershman

Portland State University

Follow this and additional works at: https://pdxscholar.library.pdx.edu/honorstheses Let us know how access to this document benefits you.

\section{Recommended Citation}

Lichtenstein-Hershman, Livia Z., "A Present-Situation Analysis and Needs Assessment of Latinx Workers in the Portland Fast-Food Industry: a Study of their Employment Journeys \& Job-Related Language Needs" (2019). University Honors Theses. Paper 687.

https://doi.org/10.15760/honors.704

This Thesis is brought to you for free and open access. It has been accepted for inclusion in University Honors Theses by an authorized administrator of PDXScholar. Please contact us if we can make this document more accessible: pdxscholar@pdx.edu. 
A Present-Situation Analysis and Needs Assessment of Latinx Workers in the Portland Fast-Food Industry:

A Study of their Employment Journeys \& Job-Related Language Needs

by

Livia Lichtenstein-Hershman

An Undergraduate Honors Thesis Submitted in Partial Fulfillment of the Requirement for the Degree of

Bachelor of Arts

in

University Honors

and

Spanish

Thesis Advisor: Kathryn A. Harris

Portland State University 


\begin{abstract}
This case study illustrates the employment journeys and experiences of three Latinx fast-food industry service workers. Analyses of in-depth interviews reveals while participants share comparable employment histories, they also demonstrate differences in regard to the paths to management they have experienced, and their level of language confidence at work. All participants in this study have been offered and have declined management positions. First, this analysis suggests there is a myriad of reasons besides a lack of English language skills regarding why Latinx fast food restaurant workers may not assume management positions. These reasons include participants lacking the following: time to devote to English language study, desire to change their shift schedule, and adequate compensation for the managerial role. Second, this analysis suggests there may also exist a mismatch between the perception the fast-food worker has of their own language skills, and their manager/supervisor's perception of their language skills and readiness to assume a managerial position. The mismatch points to a need for more English language education, which has the potential to bolster learner confidence and lessen the gap between employee and manager/supervisor perception of the employee's language skills. This study argues for employer-sponsored English language classes to support the language learning journey of Latinx employees. In turn, this would benefit the workers in their personal and professional lives, as well as the fast-food restaurants, because the more confident and proficient the employees are in their English language capabilities, the more smoothly the restaurant will operate.
\end{abstract}




\section{Introduction}

In October 2018, I embarked on the most challenging and rewarding of my academic experiences: I taught my first ever English as a Second Language (ESL) class. This was a special kind of ESL class: a multi-leveled, multi-linguistic background, free class in North Portland, home to a sizeable immigrant population with many people identifying as Latinx. In those three months of creating and delivering curriculum that responded flexibly and creatively to students needs, I got to know three women in particular, and hear their stories. The three women are sister-in-laws, were born and raised in Mexico, speak Spanish as their first language, and all three work in fast-food, in line / prep cook positions. All three women have been offered management positions during their careers, which have spanned between six to twenty-three years in the fast-food industry alone. However, all three have turned down the management position offers, and cited language capability as a major factor influencing their decisions. This piqued my interest, and I created my thesis research questions to investigate the factors that influenced the three women's decisions. While the three women inspired my project, I did also interview one participant who was not a member of the ESL class. It is my hope that by adding my voice to the conversation regarding workplace equality and the need for English for Special Purposes (ESP) adult education, I can provide a space for the voices of Latinx fast-food workers to describe their experiences. Finally, through this project I hope to articulate specific recommendations as to what kinds of ESL materials could be created and the manner in which they could be delivered to best benefit the participant population, adding my voice to the discourse community surrounding ESL pedagogy. I am extremely grateful to my participants for generously sharing with me their stories, perspectives, and time. 


\section{Background}

The existence of vocational training programs in the U.S. has decreased consistently; between 2001 and 2017 federal appropriations for Department of Labor (DOL) job training grants have sharply decreased by $40 \%$ ("Adult Vocational Training” (n.d.)). According to Reich and Cho (2017), this trend in disinvestment in our nation's workforce permeates many other programs as well; since 2001, Department of Education grants which have historically been used to fund programs that support technical schools, high schools, and career and technical education at community colleges have decreased by $34 \%$. Additionally, the Department of Education is also responsible for administering grants which help fund adult literacy programs in conjunction with other programs which support the learning of many basic skill sets. Following the same trend, funding for these programs has also declined 23\% since 2001 (after adjusting for inflation) (Reich \& Cho, 2017). It is important to note, however, that in 2014 the Obama administration did implement programs in support of contextualized education under the Workforce Innovation and Opportunities Act of 2014 (WIOA), and this relabeling of terms from "vocational training" to "contextualized instruction," may have affected these statistics. While funding may still be reduced, there has been a resurgence of contextualized instruction in recent years. WIOA is in effect until 2020, at which point the current administration will evaluate and decide whether or not to continue to authorize the act.

Educational systems are directly related to employment systems; according to Allmendinger (1989), "educational opportunities, and the specific structures of educational systems, are as consequential for mobility in labor markets as are the attributes of the individuals who make careers in those markets" (p. 231). Therefore, educational infrastructure directly 
impacts labor infrastructure and human capital. The structure of public education in the U.S. can be classified as a stratified system characterized by its failure "to equip poorer children with basic skills, combined with a longstanding under-investment in vocational qualifications" (Fleming, 2015, p. 4). Because of the contemporary lack of vocational training in the United States, the path to job-specific education can be unclear or hidden for people who are economically disadvantaged. This disconnect between vocational training and low-skill workers becomes all the more amplified in the case of populations who have been historically institutionally marginalized, such as people of color (POC) and immigrants, especially those who do not speak English fluently or whose English literacy is limited.

In the United States, the restaurant industry is the single largest source of employment for

Figure 1. The Restaurant industry is home to seven of the ten lowest paid occupations in the US, disproportionately employing people of color.

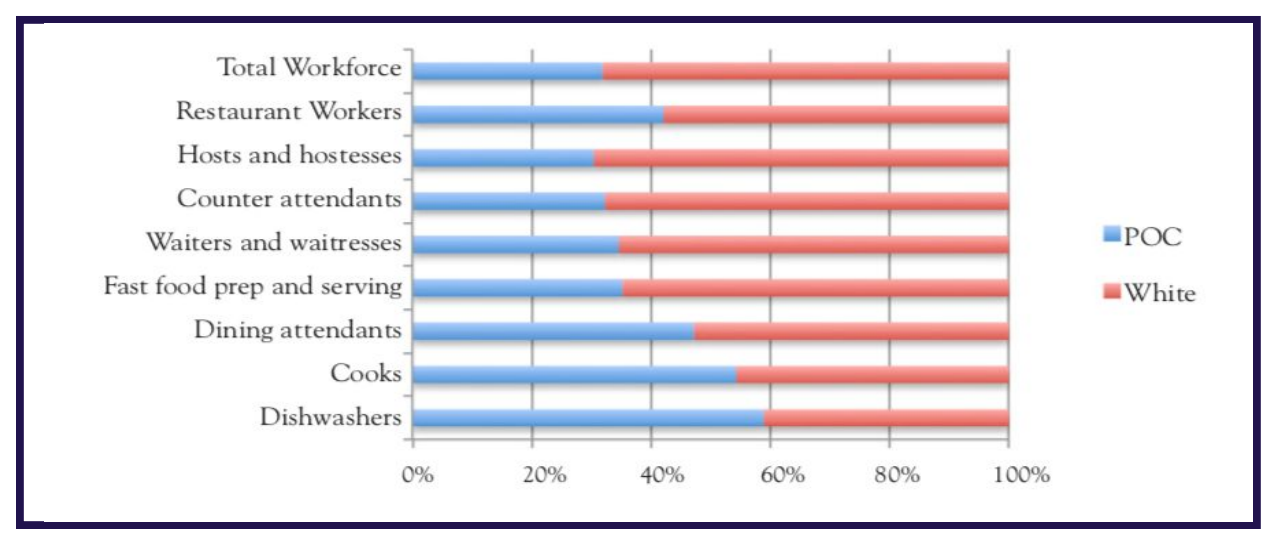

ROC-United.com, 2013
POC, and the

second largest

employer of

immigrants

(Covert, 2013;

ROC-United,

2013) (see chart at

left). However,

POC and immigrants are "disproportionately concentrated in the lowest paying [fast-food]

positions" (Covert, 2013, p. 1). According to a report by the Restaurant Opportunities Centers

United (2013), the restaurant industry accounts for providing seven of the ten lowest paid job

positions in the U.S.. When examined with an eye to racial representation, two of the 
lowest-earning job positions, dishwashers and fast-food preps and cooks, are 59\% and 35\% POC, respectively. In 2013, dishwashers nationwide earned a median wage of $\$ 8.78$, while fast-food preps and cooks earned $\$ 8.85$ (ROC United). According to the same report by ROC-United (2013), in 2013 Latinx people represented $47 \%$ of the fast-food workforce nationwide. All it takes is one visit to a Taco Bell, McDonald's, Taco Time, Burger King, Dairy Queen, Burgerville, etc. to notice the obvious presence of POC in the kitchen and behind registers in the Portland area. According to Green et. al. (2015), in Portland "persons of color, especially Latinos, and non-citizen workers are represented in food services at a rate more than ten percent higher than the regional workforce overall” (p. 32). Many Latinx employees in fast-food restaurants in Portland are native Spanish speakers (although some speak Indigenous languages as their first language [referred to hereafter as L1], and Spanish as their second language, in addition to English as a third or additional language.)

Several programs have been created to address the language needs of fast-food workers to support their success and professional growth in their industry, which fall under the term Contextualized Instruction. Contextualized instruction refers to the process of providing contextualized literacy and language skills that respond to the demands of the work environment and career aspirations (Wrigley, 2015). By contextualizing and customizing instruction, the English Language Acquisition programs operating in contextualized instruction settings aim to cater to the specific needs of English Language Learners who may not have experienced much formal education in their lives, which can be the case of many new immigrants and refugees. Some of the specific skills English language acquisition programs aim to address understanding that many immigrants do not possess these skills prior to employment are: 1) English speaking 
and listening skills, 2) academic listening and comprehension skills, 3) written communication, and 4) the culture of work and training.

Regarding speaking and listening skills, unlike for native English speakers, making the transition into a workplace with unique vocabulary pertaining to social interactions and technical tasks can be a real challenge for English language learners. In the case of one of the participants in this study, simply chatting with a coworker was very taxing when she first began her job and therefore created stress rather than camaraderie. Other tasks such as making requests, explaining mishaps when a machine breaks or when things don't go smoothly, or providing an explanation to a customer regarding a lack of a specific ingredient, can all be considered specific acquired skills. These skills can be fostered through contextualized English education.

While the second category, academic listening comprehension skills, may seem surprising considering working in a fast-food restaurant is not considered an academic setting, the same skills that foster listening and absorbing knowledge in an academic context support the ability of a worker to listen and absorb knowledge in work training situations. In the case of written communication, the writing tasks required of English language learners in the work environment often rely on previous knowledge of how to complete tasks such as filling out a form to request time off or report a critical incident, in addition to clocking in and out (Parrish \& Johnson, 2010). While many of these skills become second nature for many native English speakers since the tasks can oftentimes mimic tasks they have experienced in a school environment, they are not intuitive for people who have not grown up carrying out similar written tasks in their day-to-day educational upbringing. 
The fourth dimension contextualized instruction aims to teach, the culture of work and training, can often be the most complex. According to Wrigley et. al. (2003), immigrants often need specific training on how to navigate the workplace environment as well as how to excel in a training course itself, even if the training course is designed to teach them work-specific skills. Many people do not enter the workforce with experience working in teams, feeling comfortable asking questions, or knowing how to handle uncomfortable and potentially unethical situations such as dealing with sexual harassment or discrimination. Being able to access resources especially when it comes to finding legal and social assistance and support is a skill unto itself. Therefore, contextualized instruction programs have the potential to fill an important gap in English language learning by allowing English language learners to learn specific learning strategies. This then enables them to be better positioned to learn new language and literacy skills, as well as participate in employee training events. Wrigley (2015) sums it up articulately: "Building programs that offer instruction contextualized to work and careers helps create pathways to self-sufficiency and offers access to quality jobs for immigrants and refugees who may be underemployed or educationally underprepared and whose English is still a work in progress" (p.7).

The most robust employer provided learning program I have come across is McDonald's English Under the Arches, which was created in a collaboration between English Language Acquisition instructors and McDonald's management. The program operates with the clear aim of helping improve employee's English skills in order to support their career advancement at McDonald's, supporting McDonald's slogan “We're committed to being America's best first job ${ }^{\mathrm{TM}}$." The program currently operates at $41 \mathrm{McDonald}$ 's restaurants, and since 2007 has served 
more than 6,500 McDonald's-employed English language learners; all of the participants are either management trainees or assistant managers ("McDonald's Archways to Opportunity," 2019). The program utilizes a blended teaching model that includes both virtual and in-person classes taught by English instructors from local community colleges near each site, in addition to regional meetings to help support the community aspect of the course (Aspen Institute, 2014). Since 2008 , the program has reported an $85 \%$ rate of course completion for it's participants, a $90 \%$ year-to-year retention rate, and the benefit that a substantial amount of it's participants $(95 \%)$ have experienced increased wages following their participation in the program (Aspen Institute, 2014).

Because the existence of such programs is limited, there is still a pressing need for fast-food specific ESL education for non-native English speakers living and working here in the U.S. Several applied linguistics researchers and practitioners have addressed this need, such as Cwach and Gravely in their project with the Educational Resources Information Center \& Denver Public Schools (1997), when they created "More Water, Madam? An ESL Curriculum for Service Helpers in Full-Service and Fast-Food Restaurants.” Their project was designed through a collaboration between people in the restaurant and education industries in Denver, Colorado, and consists of a 5-lesson curriculum that can used in both full-service and fast-food restaurant contexts. Gerdes and Wilberschied (2003) have also worked to bridge the gap between language skills and capabilities in the restaurant setting through their project in which they partnered with a restaurant chain in Cincinnati, Ohio, to design a course for its employees to improve their job-related English. First they conducted a needs analysis, and subsequently designed and implemented a curriculum. 
Despite these efforts, there still exists a gap between documented, written English for Specific Purposes knowledge, and access to this knowledge in the form of education for fast-food workers. For example, while McDonald's English Under the Arches program, mentioned earlier, does show proof of employer engagement in that it is employer-sponsored and supported, it relies on the franchise owners, referred to at McDonald's as owners or operators, to select and recommend managers and managers in-training to give them access to the courses. Therefore, it is not available to all McDonald's employees (such as those in line-cook positions), and relies on the willingness of the owner at each franchise to choose to be one of the sites that offers the program. According to McDonald's website, out of their more than 14,000 restaurants, 41 restaurants operate as sites with the employer sponsored learning program English Under the Arches (“Number of McDonald's restaurants in North America from 2012 to 2017, by country"). One unique aspect of this program is the time employees spend learning English is considered paid work time, so they do not lose wages by choosing to participate in the voluntary educational opportunity.

This chasm between knowledge gained through research and the application of that knowledge in the form of contextualized education programs needs to be bridged. Because of my longtime interest in, and studies of, Latin American culture and the Spanish language, I decided to focus specifically on Spanish speakers for this research. This has helped me develop my understanding of what Latinx immigrants experience in their fast-food workplaces here in the U.S. and the role language plays in these experiences. In order to understand the existing context to determine how bridging this gap can be most effectively done, I initially crafted my thesis on the following questions:

1) What are the experiences of Latinx people working in fast-food in relation to 
language?

2) What are the specific language needs of Latinx people working in fast-food?

3) What is the path to working in management that Latinx people working in fast-food have experienced or perceive?

4) What factors influence the confidence / ability / desire to learn and use English for Latinx people working in the fast-food industry, including treatment they have experienced professionally?

After the analysis, I decided to roll my first research question into the final three because it proved to be too broad to answer. The participants' experiences are as diverse and multi-faceted as their personalities, so I found that this question functioned as a large umbrella category which did not illuminate many specific conclusions. Therefore, my research questions are the following:

1) What are the specific language needs of Latinx people working in fast-food?

2) What is the path to working in management that Latinx people working in fast-food have experienced or perceive?

3) What factors influence the confidence / ability / desire to learn and use English for Latinx people working in the fast-food industry, including treatment they have experienced professionally?

\section{Methodology}

As described above, there have been several studies conducted to determine the specific language needs of fast-food workers from diverse linguistic backgrounds. These studies fall under the applied linguistic field known as English for Special Purposes (ESP). ESP refers to "the teaching and learning of English as a second or foreign language where the goal of the learners is to use English in a particular domain" (Paltridge \& Starfield, 2012, p. 2). The goals and methods of ESP research have changed significantly over the last 50 years, and have increasingly begun to expand to take into account ethnographic data and qualitative evidence to 
form the basis of ESP curricula. According to Swales (1990), there is a need to look further than just structural and linguistic skill examinations and actually include social and contextual features to create a more holistic context on which to form the basis of ESP curricula. The effect of combining both qualitative and quantitative data collection methods increases the ability for researchers to shed light on the individual, human aspects of language learning and needs, helping ESP to maintain "its materials-driven, learner-centered and needs-responsive focus" (Belcher, 2009; Dudley-Evans \& St. John, 1998, as cited in Paltridge \& Starfield, 2012, p. 3). In order to gather qualitative data regarding the experiences and needs of native Spanish speakers working in the fast-food industry, I conducted three one-on-one interviews which served as a means through which I conducted both needs and present situation analysis. I employed specific targeted questions regarding the participants' use of language at work, as well as their unique narrative of their work experience overall, and any other things they wished to talk about (mostly relating to language and employment but also crossing into other unforeseen subject categories). The present situation analysis differs from a typical needs analysis by incorporating questions relating to the potential constraints and opportunities of a participant's external environment, to provide context for why specific needs exist and how they could best be addressed (Hutchinson and Waters, 1987). This includes the resources and materials available to the participant, as well as their overall attitude or surrounding culture in which they work.

I was interested in the personalized side of ESP, since it is important to know more than just language needs when conducting a needs analysis. In order to feel like I have a holistic understanding of the situation to the best extent possible, I wanted to look at factors beyond the immediate work environment such as people's previous experiences learning English, their 
interests in different language uses, the factors in their lives that act as barriers or support to their ability to pursue language learning, and anything else my participants saw relevant and chose to bring up in our interviews. For me, this information seems integral to being able to make specific curricular recommendations for a population. According to Paltridge et. al. (2009),"identity continues to be a research interest in the area of ESP" and in order to grasp at this, ESP research has increasingly incorporated the use of ethnographic research techniques (p. 3). Therefore, as learner needs become more diverse and individualized, so must the creation of ESP curriculum, to reflect not just the explicit job tasks a learner must be able to do, but also who the learner is and who they want to become (Belcher \& Lukkarila, 2011). Through this ethnographically-oriented / informed analysis, I was able to create detailed, "thick" descriptions of the experiences and needs of my participants, which prioritize the participant's experience over a lengthy discussion regarding the gaps in how the participant is or is not able to meet the needs of their employer (Hyland, 2006; Geertz, 1973).

In order to meet the criteria for my research, all three participants interviewed currently work in fast-food restaurant chains, and speak Spanish as their L1 (otherwise known as first language). I strove to interview both managers as well as prep/line cooks, though it was far harder to find managers who were willing to participate in interviews. I took a multi-pronged approach to recruit interview participants. First, I contacted several local non-profit organizations who work with the Latinx population, such as Voz and Western Farm Workers Association, to ask them whether or not they might know anyone interested in being interviewed. Second, I did a number of in-person visits to local fast-food chains (Taco Bell, McDonald's, Chipotle, Burger King, Carl's Jr., Dairy Queen, and Burgerville) to tell them about my project and ask whether 
anyone would be willing to interview with me. This was challenging because fast-food restaurants are very busy and unless you are ordering food employees do not have much patience to talk. Third, I contacted my previous ESL students from the community ESL class I taught at Roosevelt, in addition to reaching out to the entire community ESL practicum at PSU to see if any current teachers have any Latinx students who work in fast-food. Finally, I spoke to my Spanish class to ask for any helpful contacts, as well as spread the word by visiting the PSU cafeteria and asking staff there if any of their coworkers have worked in fast-food and may be interested in doing an interview with me. Of all the methods I employed, the only one that ended in interviews was the contact I made with previous students who were eager to be interviewed by me and for which I am eternally grateful. One of the people I interviewed was related to the ESL program coordinator from my ESL placement, so she too was related to the class I taught. All other recruitment methods were frustratingly unfruitful.

Prior to each interview, I read each participant the one-page consent letter (see Appendix A) in Spanish, outlining the purpose of my project, their rights as a participant (in short, that the interview was completely optional, confidential, and they were free to leave any questions unanswered), as well as where to send any questions or concerns they may have. I left each participant with a copy of the consent form for their reference. I then had each participant select their preferred pseudonym; two out the three participants chose their pseudonyms, while the third participant asked me to choose a name for them. The interviews lasted between 30-45 minutes, and took place in either a coffee shop or other public place close to the participant's home, or directly at the home of the participant. In one case, I did an interview over the phone, because the participant cancelled twice and then told me the only next available date was a week later and 
also a day when it was predicted to snow. While my original intent was to do all the interviews in public places, one of the participants expressed preference in meeting at her home, which I was comfortable doing. The experience of interviewing in the participant's home vs. in a coffee shop was profound; without the distraction of espresso machines and people coming in and out, both of us were able to focus and understand each other far better than in the interview I initially conducted in a coffee shop. To record the interviews I used a Sony ICD-UX560 recorder, and to transcribe them I then downloaded them onto my computer, and played them back at half speed in order to transcribe them.

\section{Results}

\section{Themes}

After transcribing the interviews, I employed an open-coding protocol (Strauss \& Corbin, 1998). First, I read the transcripts several times in order to scan for patterns of themes that occured. I did this by looking at each section / story / experience shared within the interview, and thought about which research question it spoke to. I color-coded each theme I saw, so as to organize and track them. I chose a specific font for each of the three interview transcripts, to ensure that when I take quotes out of the transcripts to illustrate my observations, they would retain their identity as pertaining to a specific participant. I then labeled each theme into the following three categories illustrated in the table below:

Figure 2. Table of themes

\begin{tabular}{|l|l|l|l|}
\hline Theme \# & $\begin{array}{l}\text { Theme } \\
\text { Description }\end{array}$ & Explanation of Theme & $\begin{array}{c}\text { Examples of Participant Interview } \\
\text { Quote Labeled by This Theme* }\end{array}$ \\
\hline Theme 1 & $\begin{array}{l}\text { Specific } \\
\text { English needs }\end{array}$ & $\begin{array}{l}\text { Information participant } \\
\text { provided that speaks to } \\
\text { any specific English }\end{array}$ & $\begin{array}{l}\text { "podría yo tomar órdenes, si supiera } \\
\text { ingles" (Guadalupe, lines 53-54) }\end{array}$ \\
\hline
\end{tabular}




\begin{tabular}{|c|c|c|c|}
\hline & $\begin{array}{l}\text { participants } \\
\text { have }\end{array}$ & $\begin{array}{l}\text { language need they } \\
\text { have identified as } \\
\text { needing themselves, or } \\
\text { as generally } \\
\text { challenging in the } \\
\text { workplace }\end{array}$ & $\begin{array}{l}\text { [I would be able to take orders if I knew } \\
\text { how to speak English] } \\
\text { "a veces sufro un poco más para } \\
\text { decirles el tiempo" (Carla, line 299) } \\
\text { [Sometimes I suffer a little more to tell } \\
\text { people the time (limits for each step of } \\
\text { the food preparation process)] }\end{array}$ \\
\hline Theme 2 & $\begin{array}{l}\text { Path to } \\
\text { working in } \\
\text { management } \\
\text { that they have } \\
\text { experienced or } \\
\text { perceived }\end{array}$ & $\begin{array}{l}\text { Information participant } \\
\text { provided regarding } \\
\text { their experiences and } \\
\text { observations while in } \\
\text { each job position, } \\
\text { noting the length of } \\
\text { time in positions, } \\
\text { interaction with } \\
\text { supervisors / managers } \\
\text { regarding advancement } \\
\text { into management } \\
\text { positions either } \\
\text { prompted or } \\
\text { unprompted by the } \\
\text { participants themselves, } \\
\text { etc. }\end{array}$ & $\begin{array}{l}\text { "Si me han dicho a volver a decir otra } \\
\text { vez está manager cuando se salió qué } \\
\text { porque no era como... shift leader } \\
\text { para... pero los dije que siento que } \\
\text { necesita todavía más inglés" (Carla, } \\
\text { lines 130-131) } \\
\text { [The last manager told me again, 'why } \\
\text { aren't you a shift leader?' but I told } \\
\text { them that I feel like I still need more } \\
\text { English] }\end{array}$ \\
\hline Theme 3 & $\begin{array}{l}\text { Factors that } \\
\text { influence their } \\
\text { confidence / } \\
\text { ability / desire } \\
\text { to learn and } \\
\text { use English } \\
\text { in the } \\
\text { workplace }\end{array}$ & $\begin{array}{l}\text { Information furnished } \\
\text { by participants } \\
\text { regarding factors } \\
\text { including emotional } \\
\text { response to work } \\
\text { environment and } \\
\text { interactions, amount of } \\
\text { free time, energetic } \\
\text { state outside of work } \\
\text { environment, and } \\
\text { community. }\end{array}$ & $\begin{array}{l}\text { "[...] el cliente me dijo "no te entiendo, } \\
\text { no se que estas diciendo" y se fue. Y } \\
\text { eso es cuando uno se siente frustrada" } \\
\text { (Rosa, lines 146-147). } \\
\text { [The client told me 'I don't understand } \\
\text { you, I don't know what you're saying.' } \\
\text { And that's when one feels frustrated] } \\
\text { "Si, una de las cosas es no tener mucho } \\
\text { tiempo porque uno sale temprano a } \\
\text { trabajar, y ya cuando regresa pues } \\
\text { regresa cansada, lo que quieres llegar es } \\
\text { acostarte a descansar un rato" } \\
\text { (Guadalupe, lines 219-221) }\end{array}$ \\
\hline
\end{tabular}




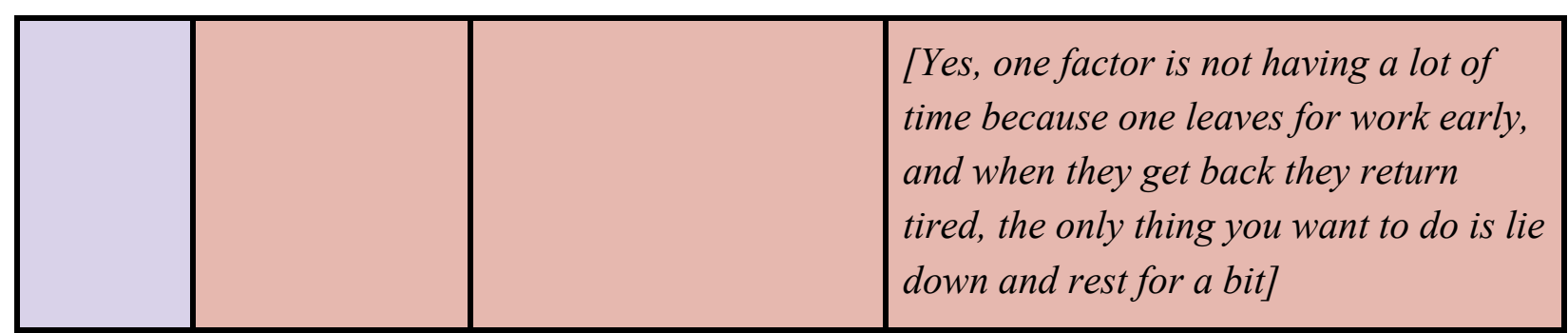

*Note: All translation of quotes has been done by me, Livia Lichtenstein-Hershman. The original participant-generated quotes are listed first, with quotation marks around them, followed by the participant's pseudonym listed in parenthesis. The translations come second, within brackets, and are italicized.

Next, I grouped the data from each theme together on a new document translating select parts of the transcription as I went, organized by theme, and within each theme, by participant. In creating this comprehensive but summarized English document capturing the themes discussed in each interview, I was able to better see the overall narrative of that theme within the experiences of my participants, while retaining the context in which each theme came up in conversation. In doing so, I was able to focus in on the sub-themes, which are shown in the table below:

Figure 3. Table of sub-themes

\begin{tabular}{|c|c|}
\hline \multicolumn{2}{|r|}{ Theme 1: Needed Skills } \\
\hline Sub-theme & $\begin{array}{ll}\text { - } & \text { Verbal skills } \\
\text { - } & \text { Confidence }\end{array}$ \\
\hline \multicolumn{2}{|r|}{ Theme 2: Management Path } \\
\hline Sub-themes & $\begin{array}{l}\text { - } \quad \text { Offered rather than asked for managerial positions } \\
\text { - } \quad \text { Mismatch between employee's language confidence and } \\
\text { supervisor / manager perception of workers language abilities } \\
\text { - } \quad \text { Timing of when management position was offered to them } \\
\text { - } \quad \text { Feelings } \\
\text { - } \quad \text { Very different perceptions of management role merits \& } \\
\text { drawbacks }\end{array}$ \\
\hline & Theme 3: Influences \\
\hline
\end{tabular}




\begin{tabular}{|l|ll|}
\hline Sub-themes & - & Feelings \\
- & Lack of English spoken at work for kitchen workers (Guadalupe \\
and Carla) & - & Work as the main place English is spoken around them during \\
& their day \\
- & $\begin{array}{l}\text { Logistics of accessing ESL education both in community ESL } \\
\text { contexts as well as employer-sponsored ESL education contexts }\end{array}$
\end{tabular}

My research questions are aligned with my themes; I coded the data by matching it to the pre-existing themes established by the groupings of my interview questions, and the sub-themes are effectively the new information I then coded for.

During the process of labeling and grouping the themes and sub-themes, I decided to integrate two themes which I initially saw as themes in and of themselves, into what now total 3 final themes. The process of doing so is explained in my research memo (Appendix D). Lastly, I examined and analyzed the relationships between the themes and sub-themes, which is later presented in my discussion section.

\section{Figure 4. Table of participant interview durations}

\begin{tabular}{|l|l|}
\hline Participant & Length of Interview \\
\hline Rosa & 32 minutes \\
\hline Guadalupe & 49 minutes \\
\hline Carla & 38 minutes \\
\hline
\end{tabular}

Figure 4 illustrates the different durations of time each interview lasted. This is provided in order to give some context for the subsequent graph, which illustrates the number of utterances within each theme per participant interview. The graph gives a sense of the weights 
each participant gave to each theme within our conversations, and how much they elaborated on specific themes versus stuck to the interview questions with short answers. Rosa, the participant I interviewed over the phone, answered the questions but did not elaborate much, which is shown in the graph as the number of utterances related to each of the three themes is the same. The other two participants spoke at length about a couple different themes they have had particularly relevant experiences with, which is shown in their graphs below. The differences in interview times mean that the number of utterances per theme is not a comparison of equivalents because some participants spoke longer, making it possible for them to touch on each theme more times. That aside, it is useful for providing a sense of the different experiences and themes each participant was most drawn to discuss.

Figure 5. Number of utterances within each theme per participant

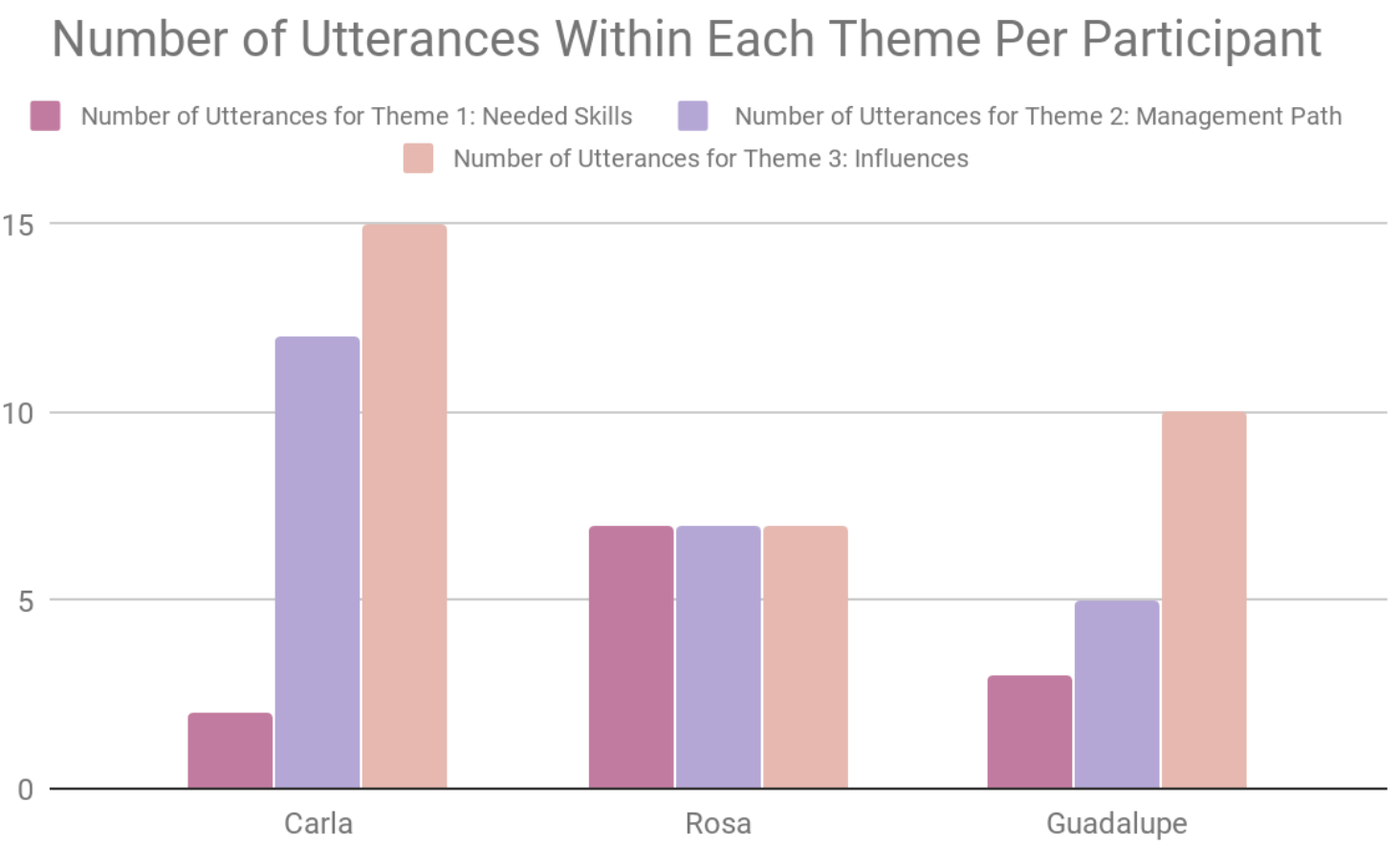




\section{Participant Demographics}

I collected basic information about each participant regarding their first name, country of origin, L1, employment position, state which they work in, and number of years working in fast-food including proportion of time at each restaurant if they have had multiple employers. I did not, however, collect any information regarding legal status or immigration history. I collected this information in order to identify similarities and differences among the participants, as well as to be able to keep track of each of their identities in an organized manner while analyzing the data I later collected through interviews. The demographic information is recorded in figure 6 below:

Figure 6. Participant Demographics

\begin{tabular}{|c|c|c|c|c|c|c|}
\hline Name & $\frac{\text { Approximate }}{\underline{\text { Age }}}$ & $\begin{array}{l}\text { Country } \\
\text { Of } \\
\text { Origin }\end{array}$ & $\underline{\mathrm{L} 1}$ & $\frac{\text { Employment }}{\underline{\text { Position }}}$ & Employer* & $\begin{array}{l}\frac{\text { Number of }}{\text { Years }} \\
\text { Working in } \\
\text { fast-food }\end{array}$ \\
\hline Carla $^{1}$ & 48 & Mexico & Spanish & $\begin{array}{l}\text { Line / Prep } \\
\text { Cook }\end{array}$ & $\begin{array}{l}\text { Purple } \\
\text { Restaurant } \\
\text { (Previously } \\
\text { the Grey } \\
\text { Restaurant) }\end{array}$ & 23 \\
\hline Guadalupe & 45 & Mexico & Spanish & $\begin{array}{c}\text { Line / Prep } \\
\text { Cook }\end{array}$ & $\begin{array}{c}\text { Blue } \\
\text { Restaurant }\end{array}$ & 15 \\
\hline Rosa & 45 & Mexico & Spanish & Manager & $\begin{array}{c}\text { Green } \\
\text { Restaurant }\end{array}$ & 11 \\
\hline
\end{tabular}

*The employer identities have been protected in order to protect the privacy of the participants. The restaurants have been coded by with color names, and shall hereby referred to by color.

\section{Researcher Positionality}

\footnotetext{
${ }^{1}$ All names are aliases to protect the identity of participants.
} 
In addition to my participants' unique voices, my research questions and analyses are also impacted by my life experiences. My interest in advocacy for populations I view as underserved influences the way I have conversations and perceive information. Because of this interest, I have studied teaching English as a second language, and am about to graduate with a TESL certificate (Teaching English as a Second Language). My identity as an English language instructor dictates a specific position with which I approached this research. While I strove to have the most unbiased interview dialogues and comb through data objectively, I am influenced by several facts: First, I genuinely like the people I have interviewed, and want to see them flourish and be empowered in whatever way they most desire. Therefore, I have undoubtedly asked follow-up questions influenced by this desire, and perhaps even missed noticing factors that someone with a different perspective and set of life experiences might otherwise see or interpret differently. Second, I have studied Spanish as my major and speaking it is one of my passions. Because I am not a Latinx person nor speak Spanish as an L1, though, I therefore have to contend with my perspective on an experience that is not my own, and all the preconceptions and interpretations which come along with that. I am a lifelong learner and wish to continue participating in these conversations to learn from the views of others. Through my participation in this study as the researcher, I myself have experienced innumerable benefits, of which I would like to name a few. First, as a Spanish major, I have gained experience conducting and translating interviews as well as analyzing data in Spanish (my L2), incorporating new skills into my repertoire of things I can do in Spanish. Second, it has been such a pleasure to interview people who have immigrated to the U.S. from Central and South America, as this population has inspired my choice to major in Spanish. As a native to western Washington County here in 
Oregon, I know Latinx immigrants are a vitally important population to our day-to-day life in the Pacific Northwest. The high school I attended (Forest Grove High School) was about 50\% Latinx and 50\% white. Latinx community members comprise the majority of the population of nursery workers, fast-food workers, and agricultural workers. I live, therefore, amongst Latinx people and I depend on their work for my sustenance. I grew up across the street from Hines Nursery, one of the largest nurseries in the country and the largest nursery in Oregon; Hines counts on an almost 100\% Latinx workforce to support all their operations. I grew up working in my family’s fields listening to music floating over from the nursery from local radio stations which broadcast almost exclusively central American music, from before the time I spoke any Spanish. Therefore, I have long thought of my work learning Spanish as a responsibility in order to know my neighbors and classmates.

\section{$\underline{\text { Restaurant context: }}$}

It is important to provide some information regarding the restaurant environments the participants described to me. While this information is not in direct response to my research questions, I think it is relevant in that it shows the environment in which the participants are operating, and allows an understanding of situational factors that influence how the participants interact and experience language at work. For example, all participants noted the ratio of Spanish to English speakers in the restaurants, and the job positions each group tends to occupy. As Carla described in response to my question regarding whether everyone who works in the kitchen speaks Spanish at her restaurant,

“[t]odos hablan espanol” (Carla, Line 296) [everyone speaks Spanish]

Rosa's account agreed with this statement, as she explained that in her restaurant 
"todas las personas que trabajamos en la cocina hablan espanol” (Rosa, line 31)

[everyone who works in the kitchen speaks Spanish]

Guadalupe presented the same description, stating:

"[e]n la cocina regularmente somos puros hispanos. Puro espanol. Los managers hablan inglés. Son Americanos, la mayoría. Hay muchos managers; son como diez yo creo. Es que la tienda es grande" (Guadalupe, lines 86-88)

[In the kitchen, usually we are all Hispanic. Pure Spanish. The managers speak English. They are American, the majority. There are a lot of managers; there are about ten I think. It's a large restaurant]

When asked how many of the managers speak Spanish, she answered

"Yo creo que nada más uno" (Guadalupe, line 90)

[I don't think more than one]

When describing the managers at her restaurant, Guadalupe stated

"cuando yo entré a trabajar la mayoria de managers hablaban espanol. Con el tiempo han ido cambiando entonces la mayoría ahora hablan inglés" (Guadalupe, lines 94-95) [when I began work the majority of managers spoke Spanish. Over time, this has changed and now the majority speak English]

When prompted to speculate as to why this might be, she said

"Antes [...] los managers que habían [...] eran Hispanos, pero pues les ofrecieron nuevos puestos, nuevos trabajos, y lógicamente que ellos agarran donde les pagan más"

(Guadalupe, lines 104-106)

[Before, the managers were Hispanic, but they were offered new positions, new jobs, and logically they went where they got paid more]

\section{Analysis \& Results}

The following section regarding the data's response to research question \#1 is organized by participant; first, I discuss Carla’s specific English language needs, which overlapped slightly with Guadalupe's. I then discuss Guadalupe's specific English language needs, and then Rosa's. 
While Carla and Guadalupe shared a few similarities because they had the same job position, they did point out several different needs, and Rosa's needs didn't overlap with the other two likely because of her different job position, which required different language skills. Therefore to do this variation justice, I am looking at the participants as people with individual needs rather than a common, generalizable experience. On that note, one of the participants brought up something that falls outside of my research questions. Please see Appendix E: A Note on the Intersectionality of Race, Ethnicity, and Language for more information.

Research Question \#1: What are the specific English language needs of Latinx people working in fast-food?

The first need that participants highlighted is the need to be able to speak more quickly / fluidly, in order for customers \& co-workers / supervisors to better understand them. Carla, who is not a manager and is not very interested in becoming one, explained some circumstances in which she wishes she were able to do this in the following excerpt:

$\mathrm{L}:$ ¿[H]ay algo que ha mencionado que le gustaría poder hacer en ingles?"

[L: Is there anything you have mentioned that you would like to be able to do in English?]

C: "Hay, pues, hablarlo... mas rápido."

[C: Yes, to speak faster.]

L: “¿Más rápido? Ok. Pero como, no se, alguna situación en que prefería hablar en inglés pero no tienen las palabras ahora?"

[L: Faster? Ok. But, I don't know, is there any situation in which you would prefer to speak in English but you don't have the words to do so right now?]

C: "[M] gustaría [...] como la muchacha como te digo que se sentaba que se llevaba unas ahi, esa hora si me gustaria saber mas ingles para decirle... pero pues como a ella le decía uno algo y ella decía "no me importa..." siempre fue así." (Carla, lines 285-293) [C: I would like to, like, with the girl that I told you about who sat [in her office] and brought other employees in there [to talk with her], I would have liked to know more English to be able to tell her... that... well if anyone told her anything she would say 'I don't care,' it was always like that.] 
To provide context for this excerpt, Carla was explaining to me some bad management practices she endured under one particular manager who has since been fired. The manager would call her favorite employees into her office, and then sit and talk with them for an hour or more, leaving the rest of the kitchen workers to pick up the slack in the absence of their coworkers. This really bothered Carla. She stated that if she had been able to speak English more quickly and with more confidence, she would have been able to speak up and say something to the unethical manager. This highlights the need of employees to have sufficient language skills to be able to navigate situations of workplace conflict and issues related to management in order to advocate for their rights. For Carla, the fluency and speed of her verbal skills is what she pointed to as the factors that prevented her from being able to do so. However, there are undoubtedly other skills which can be taught in the context of a contextualized instruction program which could also facilitate Carla's ability to address these issues with her supervisor or even branch manager (or other comparable supervisor above her immediate manager's position). Wrigley (2015) reinforces this idea, discussing how contextualized employment-related English education programs can support the formation of skills which can lead to greater self-sufficiency.

The second language need participants highlighted was the ability to confidently use numbers to explain the timing of cooking each food item in the kitchen. Carla explained that it is not her own performance that is affected by this because she already has all the times memorized, but when she is tasked with training a new employee, she has a hard time telling the trainee how long to cook each item. Here is how Carla explained it in her own words:

L: “[C]on los demás con quién trabaja usted, ¿hay algo que le gustaría poder hacer en ingles con los además en la cocina? ¿O todos hablan espanol?” 
[L: With the rest of the people whom you work with, is there anything that you would like to be able to communicate in English with the folks in the kitchen? Or do they all speak Spanish?]

C: "Todos hablan espanol."

[C: They all speak Spanish.]

C: "Pero cuando entra alguien que habla en inglés que nos toca decirles cómo se prepara la preparación, es cuando a veces sufro un poco más para decirles el tiempo, como cada cosa lleva su tiempo[...] les digo dos o tres veces hasta que me entiende." (Carla, lines 294-302)

[C: But when someone comes in who speaks English and we are entrusted with training them how to make things, that's when I sometimes suffer a bit to tell them the length of time to cook each item because each thing has its own time, [...] I say the number two or three times until they understand me.]

The third language need mentioned having is the ability to confidently take orders from customers. Confidence is one of the two sub-themes for this category, and I will devote further time to discussing it at the end of this section. In Carla's words, which also speak to the need of verbal speed mentioned above,

“[D]ebe estar tomando la orden rápido, rápido, te confirman que ya tomé yo las ordenes cuando no hay nadie ahí, entonces si no hay ni modo que otro queda, si no yo no me pongo..." (Carla, lines 416-417)

[It's necessary to take the order fast, fast, I can tell you that I only take orders when almost nobody is there, in cases when there is no other option, if not I don't do that task...]

The ability to take orders is one of the skills that currently made her nervous at the time of our interview, since the need to interact with customers required verbal skills beyond her present capabilities. This is very similar to Guadalupe's experience:

L: “¿Está satisfecha usted con su posición de ahora?”

[L: Are you satisfied with your current position?]

G: "Mmmm, si, estoy satisfecha..."

[G: Mmmm, yes, I am satisfied...]

L: “QQueria anadir mas?"

[L: Did you want to add anything else?] 
(both laugh)

G: "Si estoy contenta pero a la vez no porque también cómo no se ingles si podria yo tomar órdenes, si supiera ingles." (Guadalupe, lines 49-54)

[G: Yes I am content but at the same time I am not, because I don't know English, I would be able to take orders if I knew English.]

Guadalupe, who worked in the kitchen, had a much stronger desire to become a manager than Carla, and was therefore adamant that if she knew more English she would be able to take orders, and that would be one of the necessary skills to become a manager. The differences amongst the participants in terms of their desires to be managers is another topic entirely, which will be addressed in the following section in response to research question \#2.

The fourth language specific skill that was highlighted as something a participant is lacking is the ability to offer both corrective and positive feedback, in this case from Rosa (a supervisor) to the kitchen staff (the people she manages). Rosa explained:

$\mathrm{R}$ : "[L]as personas que hablan en ingles para mi se me hace dificil porque si yo tengo que decir a uno "ahh puedes quedar más tiempo" se me hace un poquito más complicado [...] "o que buena hamburguesa" o "que buen trabajo haces" [...] nosotros tenemos que ver en qué lado se necesita ayuda y entonces para que tu puedas motivar a un empleado necesitas, yo aveces tengo las palabras pero no las puedo a decir en inglés." (Rosa, lines 96-106)

[R: The people who speak English for me are difficult because if I have to say to one 'can you stay for more time today' it's a challenge [...] or 'what a good hamburger' or 'what a good job you do' [...] we [as managers] have to see where help is needed and in order to motivate an employee, sometimes I have the words but I can't say them in English.]

The vocabulary and sentence structure for offering positive encouragement and corrective feedback are both things that can be taught, and which are integral to being a successful manager. Rosa demonstrated in her awareness that she would like to be able to do these verbal tasks that she had the leadership capacity necessary to be a manager, but lacked the linguistic 
skills to carry out the leadership responsibilities. This relates to her overall need to coordinate the staff she managed as well as communicate with her own supervisor, and how she felt she lacks the skills to be able to do that. In Rosa's words:

R: "Como, lo que acabo de decir como poder aprender mas a como coordinar la gente, como decir "patrón, eso no se tiene que hacer, necesitamos más gente, necesitamos más esto, mas cosas, mas esto," o sea para mejor funcionamiento de la tienda y de los empleados."

[R: Like I just mentioned, if I could learn more about how to coordinate people, like to be able to say 'boss, we shouldn't do that, we need more people, we need more of this, more of that,' in order to help both the store and it's employees to better function.]

L: “¿Eso tiene que ver mucho con la comunicación entre usted y su manager?

[L: Does this relate to the communication between you and your supervisor?]

R: "Si, mi supervisor. Son mas arriba que yo." (Rosa, lines 114-118)

[R: Yes, my supervisor. They are higher up than I.]

In the case of being able to offer corrective feedback to the kitchen staff she manages, Rosa

mentioned that the very sanitation of the restaurant depends on this skill:

“"Daniel, you don't need to take the hands, you need to take the tongs ${ }^{2}, '[\ldots]$, no tenemos que agarrar el chicken con la mano. Tenemos que usar una pinza. Entonces tenemos que corregir a ese empleado que habla inglés, [...]'Daniel, no puedes hacer eso, tienes que usar tus pinzas para agarrar una chicken.' O por ejemplo, vino un empleado que no trajo su uniforme completa, se me hace dificil 'ok yuri, no traes tu pantalón, te voy a mandar a tu casa.' O sea, cosas de esas se me hace muy difícil.” (Rosa, lines 123-129)

['Daniel, you don't need to take the hands, you need to take the tongs,' [...] we don't grab the chicken with our hands. We have to use tongs. Sometimes we have to correct this employee who speaks English, [...] 'Daniel, you can't do that, you need to use your tongs to grab the chicken.' Or, for example, an employee showed up to work without their complete uniform, and it was a challenge for me to say 'Ok Yuri, you didn't bring your pants, I am going to send you home.' Like, these things are a challenge for me.]

\footnotetext{
${ }^{2}$ Rosa began this sentence by giving an example of the kind of feedback she gives in English to the people she supervises, and finished her sentence in Spanish. She was explaining that she had to give Daniel, a line cook, corrective feedback because he was grabbing chicken with his hands rather than using tongs, which violates sanitation procedure.
} 
This highlights the need of managers / supervisors to be taught the vocabulary and sentence patterns to offer corrective feedback in the case of employee etiquette, food safety, and sanitation practices. Rosa explained that she tries with repetition to get her point across, but it is a challenge for her (as we see in how she formed phrases in English in the above example) to offer the feedback in a grammatically-correct form. In the case of grabbing chicken with the hands rather than tongs, the health of customers depends on the ability of the manager to get this corrective point across to the kitchen worker.

The fifth skill is the ability to have a dialogue. Again, this is something that Rosa, as a manager, highlighted, since she is in the position of having to coordinate with both her kitchen staff as well as her own manager. She even cites her lack of confidence in having a dialogue in English as one of the reasons she would like to return to her role in the kitchen instead of continuing as a manager, stating:

"Pues para mi seria mejor que en una posición diferente, como en la cocina, porque no tienes que tener diálogo con los clientes, no tienes que tener mas dialogo con otras personas, porque es muy frustrante." (Rosa, lines 40-46)

[For me, it would be better to be in a different position, like in the kitchen, because there you don't have to converse with the customers, you don't have to converse with anyone, because [conversing] is very frustrating.]

Conversation skills come with practice and time. Therefore, this is the most broad of the skills highlighted by the participants as things they are lacking. However, it seems to be at the core of the next and final factor: confidence. The participants all linked the lack of ability to converse with other people in English as the primary reason why they either don't picture themselves as comfortable and capable in a future management position, or as apt to continue in their current management position (in Rosa's case). 


\section{Summary of Participants' Workplace Language Needs}

Although each participant described having different English language needs, all of the needs do fall under the category of verbal skills, which is the primary of the two sub-themes in research question \#1: Needed Skills. In a work environment where most communication is verbal, all three participants cited different aspects of verbal communication as language challenges that hold them back from feeling confident in taking orders, giving feedback and encouragement, and speaking up for their rights as employees. Verbal skills are teachable and the umbrella category for almost all of my specific recommendations in terms of ESL materials and lessons to be created to address these language needs. The second subtheme of this research question regarding needed skills is confidence. Some of the excerpts cited in the preceding section touch upon this sentiment; although confidence is less of a specific teachable skill and more of an emotion/feeling that comes with more practice, all three participants cited confidence as something they are lacking. This mismatch in perception between the manager's opinion of the English language abilities of the employees, and the employees' own opinions of their English language capabilities, will be further discussed in the following sections.

Through this ethnographically-oriented / informed analysis, I created a detailed, "thick" description of the needs and experiences of my participants, presented in a manner which prioritizes a discussion of the participant's experiences over a description of the gaps between the participant's skills and the expectations of their employers (Hyland, 2006; Geertz, 1973). Based on the preceding descriptions of participant's needs, I offer the following strategic recommendations: 
If restaurant managers want kitchen workers to move into management positions, I suggest that fast-food employees be given the opportunity to practice verbal skills in realistic situations which actively facilitate confidence building. This does require that employees either have access to an ESL class where the teacher can cater to their needs, or that their employer offers an employer-sponsored English language learning opportunity. Regardless, practicing the verbal exchanges pertaining to realistic situations in which employees communicate with their supervisors, customers, and co-workers, has the potential to bridge the gap between the kitchen worker's self perception of their language skills, and the outsider (manager) perception of the kitchen workers' language skills. In the case of the participants in my study, the types of exchanges in which they want to be more proficient are dialogue between customer and worker when it comes to modifying orders, dialogue between supervisor and worker when it comes to giving positive and constructive feedback, and dialogue between supervisor and repair person when a machine breaks. Because I gathered information about both the specific language tasks that pose challenges for the participants as well as the other influences in their lives that impact their language use, I believe I am able to successfully shed light on the individual, human, aspects of language learning and needs. This operationalizes the need for English for Specific Purposes to be learner-centered, needs-responsive, and materials-driven (Belcher, 2009; Dudley-Evans \& St John, 1998, as cited in Paltridge \& Starfield, 2012). Hutchinson and Waters (1987) agree that identifying the context for why needs exist and the manner in which materials can be best delivered to the learner is integral to a successful present situation analysis. During interviews, the participants in this study mentioned specific situations that cause them problems 
with English use. The following is a list of tasks that could be addressed with materials I suggest be created:

- Telephone call skills in case of a machine breaking and needing to communicate with a repair company

- Conflict management

- Small talk

- Feedback giving and receiving

- Numbers

- Initials

- Pronunciation

To address the English language needs of fast-food workers, I suggest an employer-sponsored program as the most learner-centered option, because it builds an English language class into the employee's schedule in a way that does not prohibit them from working or cause them to spend money. This approach also communicates that the employer shares the responsibility along with the employee for creating a dynamic and logistical situation in which the employee has the time to devote to language study. An approach to contextualized learning that I find particularly appealing is the I-BEST (Integrated Basic Education and Skills Training) model, the positive attributes of which are supported by research evidence (Zeidenberg \& Jenkins, 2010). This approach is characterized by the teamwork of a technical instructor and an adult basic education or English language acquisition instructor who work together in the same classroom, combining basic language skills with occupational skills.

Research Question \#2: What is the path to working in management that Latinx people working in fast-food have experienced or perceive? I noticed the most variation among responses and sub-themes in this theme, as the narratives voiced by each participant are quite different. Therefore, I have divided this section into two subsections: commonalities and differences among the participant's experiences and responses to 
my questions. Even in such a small sample, for some sub-themes participants had experienced the path to management in nearly identical ways, while for other sub-themes, they had different experiences to one another. First, I will describe some of the commonalities.

\section{Commonalities:}

The first commonality (and subtheme) we see between all the participants is that all three women have been offered management positions, but never asked for them. Second, they have all three turned down the positions, (though Rosa eventually accepted the position and is currently a manager), citing lack of English skills as the main reason when explaining their decision to decline the position to their employers. In Guadalupe's words,

G: "Ehh, hace como cuatro años, ehh me dijo un manager que yo sabía preparar cosas, y sabía todo todo los... que yo sabía hacer las hamburguesas que yo sabía preparar la comida, que yo podía tomar el puesto de manager, pero yo lo dije que no, que yo no sé inglés."

[Ehh, about four years ago my manager told me that I knew how to make everything, do everything... that I knew how to make the hamburgers and prepare the food, that I could take the position of manager, but I told him no, because I don't know English.]

L: "¿Y que dijo a eso?"

[L: And what did he say to that?]

G: "Él dijo que estaba bien, que yo podía tomarlo porque yo si sabia hacer las cosas, y yo dije que no." (Guadalupe, lines 33-38)

[G: He said that it was fine, that I could take orders because I knew how to do everything, and I told him no.]

Carla spoke to this same reasoning behind her decision to decline the management position offered to her, stating:

L: "¿[A]lguna vez su empleador le ofreció un rol diferente en su trabajo?”

[L: Has your employer ever offered you a different position at work?]

C: "Si, aqui en el [purple restaurant], pero dije que no."

[C: Yes, here at [purple restaurant], but I said no.]

$\mathrm{L}:$ ¿Y esto fue la primera vez? ¿O ha pasado antes?”

[L: And was that the first time? Or had it happened before?] 
C: "Ya me dijo ella, fue la que ya me dijo dos veces. La misma manager me dijo como tres semanas atrás, otra vez. ¿Y porque no? Porque... y si lo que me dijo ella es que 'yo quiero que seas shift leader para que tu apures a la gente para que trabajan mas rapida.' [...] Pero la dijo que no, que necesitaba yo mas ingles, y me dijo, pues, en ingles, que si estamos hablando en inglés ahora y nos entendimos, porque no? Pero cuando hay un problema y uno se olvida todo, y ya no puedo..." (Carla, lines 142-154)

[C: She had already asked me, it was her who asked me twice. The same manager asked me about three weeks prior, again. And why not? Because... she told me 'I want you to be a shift leader so that you can hurry the people so that they workfaster.' [...] But I told her no, that I needed to know more English, and she told me, well, in English, that if we are speaking in English right now and we understand each other, why not? But when there is a problem one forgets everything, and I can't...]

Rosa also felt this way, even though she is currently in a manager position and has been for the last year and a half. She told me:

L: “Le gusta las nuevas responsabilidades de ser manager?”

[L: Do you like the new responsibilities of being a manager?]

R: "Sí me gusta, pero para mi como no hablo perfectamente el idioma, se me hace difícil." [...]

[R: Yes I like it, but for me because I don't speak the language perfectly, it is a challenge.]

L: "Entonces con el rol, ¿siente satisfecha usted con las posición en [green restaurant]? O quisiera lograr tener un posición diferente?"

[L: So in terms of the role, do you feel satisfied with your position at [green restaurant]?

Or would you like to achieve a different position?]

R: "Pues para mi seria mejor que en una posición diferente, como en la cocina, porque no tienes que tener diálogo con los clientes, no tienes que tener mas dialogo con otras personas, porque es muy frustrante."

[R: Well, for me a different position would be better, like in the kitchen, because there you don't have to talk with customers, you don't have to talk with other people [in

English], because that is very frustrating.]

L: "Ahh ok. Y entonces ¿está pensando en cambiar otra vez a trabajar en la cocina?"

[L: Ahh ok. So you are thinking about changing back to working in the kitchen?]

$\mathrm{R}:$ "Si."

[R: Yes.]

L: “Si? Ahh ok. ¿Y cómo va a hacer su decisión?”

[L: Yes? Ahh ok. And how are you going to decide?] 
R: “Ahh, yo ya hable con mi store manager y ella pues, dice que estoy haciendo bien, que no necesito cambiar, pero yo no me siento ajusto en este puesto.” (Rosa, lines 28-50) [R: Ahh, I already spoke with my store manager and she told me that I am doing everything well, that I don't need to switch jobs, but I don't feel comfortable in this position.]

Also within these quotes, we see evidence in the sub-theme of a mismatch between the worker's confidence in their language abilities, and their supervisor / manager's perception of their skills and readiness to assume leadership roles. Rosa, then a manager herself, even spoke with her current supervisor about her concern that she was not doing her job well enough because she didn't feel confident speaking English. Her manager assured her that she was doing a good job, and discouraged her from changing back to a role in the kitchen. Even so, that is an option she was still considering at the time of our interview. She said after a year and a half of being a manager, she still didn't feel adjusted to the position and comfortable in her role, which was stressful. With both Carla and Guadalupe, both of their supervisors told them they thought their English was sufficient to support their success in management positions. They both disagreed with this assessment, pointing out that while they can communicate in calm situations, they feel nervous about having to solve problems, talk to angry customers, or check in with franchise owners in English. Carla explained her hesitations:

"Entonces cuando no estoy nerviosa o eso, si, puedo platicar un poco más pero si hay un problemo y más si un cliente se enojó, me espanto y ya me salen las palabras." (Carla, 157-158)

[When I am not nervous or anything, I can converse a little bit more, but if there is a problem or worse, an angry client, I get scared and the words don't come out.]

Guadalupe explained her reasoning, stating:

G: "[C]uando llega el dueño, entonces ahí los managers ya hablan con él cuando hay alguna situación que hay que arreglar algo [...]" 
[G: [W] hen the owner arrives, the managers talk with him when there is anything that needs to be resolved / arranged [...]]

L: "Y pensando en este situation..."

[L: And thinking of that situation...]

G: "Pensando en esa situación, dije que no [...]"

[G: Thinking of that situation, I said no [...]

L: "Si, ok. ¿Porque se pone un poco nerviosa?"

[L: Yes, ok. Because it makes you a little nervous?]

G: "Si." (Guadalupe, lines 40-46)

[G: Yes.]

Another striking commonality between all three of the participants (and the third

sub-theme within this section regarding management path) is the significant length of time they

all spent working in their respective restaurants prior to be offering management positions. In the case of Rosa, she was offered her management position at the almost-10-year mark of working at the green restaurant. Guadalupe was offered a management position after 11 years working at the blue restaurant, and Carla was offered a shift leader position after 22 years working at the purple restaurant and the grey restaurant (she has worked on and off at both restaurants since 1995). All three of them are some of the most long-standing employees at each of their restaurant locations, and have seen many different managers and fellow employees come and go.

The last sub-theme apparent within the management path research question category is the commonality of feelings each participant associates with the role of manager. The words the participants used to describe their hesitations regarding becoming managers themselves are: nervous, uncomfortable, lacking in confidence, feeling un-adjusted, and feeling stressed. The commonality among these emotions is the connotation of negativity we associate with these feelings, which correlate with the amount of hesitation the participants discussed when describing their thoughts and opinions on becoming managers. 


\section{Differences:}

As previously mentioned, of the three participants, only Rosa has accepted a management position. However, it is important to note she now wishes she could return to the kitchen, citing the stress of not speaking fluent English as a factor that creates a lot of stress for her within her role as manager. The reasons why Carla and Guadalupe both turned down the management positions offered to them also differ, for reasons other than their hesitation with speaking English: Carla explained that she did not want to have to take on more stress, work faster, and only earn $\$ 1$ more per hour for all the additional responsibilities. In Carla's words, "[...] $[\mathrm{N}]$ o me gustare. Yo veo que luego se estresan mucho. Es mucho trabajo, es que les exigen mucho en el tiempo" (Carla, 407-408)

[...][I wouldn't like it [being a manager]. I see that the managers are very stressed. It's a lot of work, it's that a lot is expected of them in little time.]

Regarding the small difference in pay, Carla said:

"[C]reo que nada les dan como un dólar más"

[I think they are only given a dollar more [per hour, in comparison with kitchen workers] (Carla, line 431)

"[N]o es mucho para tanto estrés y el tanto que les exigen." (Carla line 442) [It's not a lot for all the stress and things demanded of them.]

Regarding how she would have to change her shifts to accommodate the new role, Carla stated:

"[E]1 hacerse también shift leader significaria que ya lo cambian de turno porque la que está en la mañana siempre ha tenido su turno en la mañana. Entonces sería cambiarme turno a la noche, o los sábados y domingos, y yo cuando entré aquí el año pasado fue cuando pedí sábados y domingos para descansar, todo la vida los trabaje como mis niños estaban chiquitos, entonces era más fácil tener mi esposo con los hijos durante el día." (Carla, lines 372-377)

[By becoming shift leader that would mean I would have to change my shifts because the shift leader that works in the morning has always worked in the morning. Therefore, I would have to work at night, or on weekends, and when I started here last year, that's when I asked for weekends off to rest, because up until then, for my entire life, I had 
always worked nights and weekends since my kids were little, and it was easier to have my husband care for them during the day.]

We see that for Carla, the decision to decline the position had to do with both the additional stress, the relatively insignificant compensation, and the change of shifts she would have to accomodate, in addition to the need to speak English more frequently while at work. This contrasts with Guadalupe's reasoning. She wholeheartedly wants the change of pace and new responsibilities being a manager would bring, stated she would feel less stressed out by the pace of work if she was in a management position, but the only thing holding her back is that she just doesn't feel ready yet language-wise. However, she really looks forward to being able to talk with customers more, because she enjoys all the short interactions she has with them.

G: "Ehh, la ventaja de ahí de los managers es este una que no trabajan mucho en la cocina porque trabajar en la cocina es un poco más pesado que estar tomando ordenes. Porque está uno en una temperatura, las parrillas están muy calientes, la temperatura esta uff muy caliente y tener mucho cuidado de no quemarse los manos." (Guadalupe, lines 125-128)

[G: Ehh, the benefit of being a manger is that you don't have to work in the kitchen much, because working in the kitchen is harder work than taking orders. Because it's really hot in the kitchen, the grills are really hot, the temperature is uff super hot, and you have to be very careful not to burn your hands.]

An additional factor that Guadalupe shared as something that makes her nervous about becoming a manager is the responsibility of handling money. In Guadalupe's words,

G: "[Y]o me da miedo tambien, con el dinero. Yo me da miedo porque también como es mucho se vende mucho, hay mucho dinero, es mucha este clientela, y hay que estar como bien concentrado para dar bien el cambio, porque cuando hacen su corte de caja cada dos horas creo, ellos sacan todo su... y ahí si alguna caja salió corta, te dicen que salio corta una caja. [...] Ese tambien es estresante."

[G: The money scares me a lot. I am scared because it's a lot of money since there is so much business, there is a lot of money, many customers, and you have to really concentrate to give correct change, because when the cash registers get counted every 
two hours I think, they take out your [cash], and if you come up short, they tell you that you came up short. [...] This is really stressful.]

L: “¿Pero el acto de hablar con los clientes no es tan estresante?"

[L: But the act of talking with the clients is not so stressful?]

G: "No." (Guadalupe, lines 402-412)

[G: No.]

While Carla associates the role of manager with stress, overwhelming communication requirements, and only marginally higher pay, Guadalupe associates being a manager with less stress, less heat (because of less time spent in the kitchen over the grill), and more opportunities to converse with customers, which she likes doing. Rosa, on the other hand, asserts that the very factor that Guadalupe is looking forward to, being able to talk with customers, is the thing that makes her the most uncomfortable in her position, along with talking with fellow staff and supervisors. What excites one participant overwhelms another. The barriers and diversity in reasons, whether personal, linguistic, or otherwise, in even a small sample size, show that while language certainly plays a role, it is not the only variable at play. This is reinforced by Allmendinger (1989), who concurs that "educational opportunities, and the specific structures of educational systems, are as consequential for mobility in labor markets as are the attributes of the individuals who make careers in those markets" (pg. 231). While access to English language education is one factor in the decision of each of the three participants to accept or decline the management positions that have been offered to them, my findings as well as the research of Allmendinger demonstrate that individuality is an equally impactful influence on whether or not an employee will rise to a management position. 
Research Question \#3: What factors influence their confidence / ability / desire to learn and use

English for Latinx people working in the fast-food industry, including treatment they have experienced professionally?

The first sub-theme that came up time and time again is the role of emotions and their effects on one's desire and motivation to learn a language (in this case, English). While this is an entire applied linguistics topic in and of itself, I do wish to discuss how it is relevant to the participants I interviewed. The participants associate a gamut of emotions with their experience learning / using English in the work environment. The singular emotion Rosa attributed to her experience with English in the workplace is frustration; she mentioned it three times in her interview. In all three instances, she associated it with the action of having a conversation with either coworkers, supervisors, or customers. In Rosa's words,

"[C]uando tu hablas perfectamente inglés, lo dices rapido, y cuando no hablas así, el cliente me dijo "no te entiendo, no se que estas diciendo" y se fue. Y eso es cuando uno se siente frustrada." (Rosa, lines 145-147) [When you speak perfect English, you speak quickly, and when you don't speak like that, the client told me 'I don't understand you, I don't know what you are saying' and he left. And that's when you feel frustrated.]

The emotion Guadalupe associated most with her experience speaking English in the workplace is stress, but not in the way that Rosa does; Guadalupe asserted that if she were a manager, she would be spending more time talking with customers and therefore experience less stress because she finds this more enjoyable than cooking in the kitchen. In her words,

“[M]e gustaría eso porque también está uno tomando órdenes al estar tomando órdenes como ahi mas este espacios de platicar con los clientes, no platicar pero si "hola, como estas, etc." menos estrés. Ah hah." (Guadalupe, lines 135-137) [I would like this because when you are taking orders, there is more space to chat with customers, well not chat but you know, 'hi, how are you, etc.' Less stress. Ah hah.] 
This is the precise part of being a manager that is most stressful for Carla and Rosa. Another emotion Guadalupe associates with the role of being a manager is fear in the case of giving incorrect change. The subtheme of emotions crosses over a lot in both my first and second research questions regarding needed skills and management path, as it is both a factor that affects how a person perceives and experiences the path to management positions, as well as how they experience English language use in the workplace.

The emotion Carla associated most with the idea of being a manager and using more English in the workplace is stress, which she mentioned three times. Again, this is a crossover theme with the management path research question, because she associated this emotion specifically with the idea of being a manager, as discussed earlier.

The next sub-theme that came up is a lack of English spoken at work for the two participants who work in the kitchen. This appears to be a factor which affects the participants ability / desire to use English in the workplace, because it would be a big leap for them to become managers and suddenly be expected to speak English for a large percentage of their daily interactions. In my interviews with each of them, they explained that they only take orders when there is nobody else available to do so, and when the restaurant is largely empty. Because they explained to me the workplace demographics as being largely only Spanish speaking in the kitchen, they communicate most of their daily interactions with their coworkers in Spanish.

The third sub-theme that arose in the data corresponding to this research question of influences on the participants is the reality that work is the main place that the participants are around spoken English during their day. When I asked Guadalupe, our conversation went like this: 
L: "Queria saber si además del trabajo, ¿pasa usted mucho tiempo en lugares donde la gente están hablando ingles?"

[L: I would like to know if, besides at work, you spend much time in places where the people are speaking English?]

G: "No, el trabajo es el único lugar." (Guadalupe, lines 213-215)

[G: No, work is the only place.]

Therefore, if the only context in which the participants are around English and required to speak it is at work, this really limits their exposure and creates a specific association with the language.

The final sub-theme that I noticed within the data relating to my third research question addressing influences on the participant's language use is the logistics of ESL education availability to fast-food workers, either in community ESL settings or employer-sponsored ESL program settings. For two out of the three participants, the availability of free English classes taught by ESL teachers who speak Spanish offered in the area was something they labeled as a barrier to improving their English. I knew that both Guadalupe and Carla had both taken a community ESL class because I happened to be the teacher for that class, however, I didn't realize that a major driving factor for why they attended my class is that I speak Spanish. Both participants mentioned this as a major factor in why they had not pursued much in the way of any formal English language education prior to attending my class. In my interview with Carla, she asked me about the new teacher at the site where I taught several months prior. I responded:

L: “¿Recuerda el chico que vino para mirar nuestra clase? Es él que va a enseñar la clase ahora."

[L: Do you remember the guy who came to watch our class? He is teaching the current class.]

C: "Ahh. ¿Y habla espanol?” (Carla, 140-141)

[C: Ahh. And does he speak Spanish?] 
During my interview with Guadalupe, I asked her about her previous experiences with English language learning:

L: "Entonces antes de venir a la clase de inglés que enseñe hace unas meses, ¿nunca ha ido a otras clases [...]?"

[L: Before you took the English class that I taught a few months ago, had you ever attended other English classes [...]?]

G: "No, si ya tiene como tres años que quise ir a una clase así, pero la maestra no hablaba español, entonces me dificulto muchísimo." (Guadalupe, lines 188-195)

[G: No, it had been about three years that I'd been wanting to attend a class like that, but in the past the teacher didn't speak Spanish, so it was very difficult for me.]

Prior to these interviews, I did not realize how important it was to my participants to attend English classes taught by a bilingual teacher.

Another component of this sub-theme is the availability of work-sponsored English classes for the participants. Rosa is the only participant who has experienced English training at work in the form of an employer sponsored learning program, discussed earlier in the background section. Neither Guadalupe nor Carla have experienced any such program, even though Guadalupe works at the same company as Rosa. As previously mentioned, employer sponsored learning programs can vary franchise to franchise, within the same chain. The presence of each program site depends on employer buy-in. Regarding her language growth after being a part of the program, Rosa commented:

"Sí he aprendido un poco más, como por ejemplo hay cosas que yo no entendía que ahora ya entiendo un poco más, y ya tengo mas confianza pero aun si todavia se te puede decir que tenía el 5\%, avance $25 \%$, pero todavía me falta un 70\%." (Rosa, lines 75-77) [Yes I have learned a bit more, like for example there are things that I didn't understand that now I understand a bit more, and I have more confidence but even so I can still say that I had 5\%, I advanced another 25\%, but I still have another 70\% to go]. 
Even despite Rosa's completion of the program (and her place as a member of the $85 \%$ of people who have completed the course and seen subsequent wage increases in connection with their new management positions) (Aspen Institute, 2014), she still does not report feeling confident in her new role. The final two factors that can present barriers to accessing ESL education for the participants are a lack of free time and sufficient money. In Rosa's words,

"[P] ersonalmente, yo llego cansada, tengo que hacer esto, esto, y esto, ya no me da tiempo suficiente, y ya uno no quiere agarrar tiempo para ir a estudiar." (Rosa, lines 151-153)

[Personally, I arrive [home from work] tired, I have to do this that and the other, and don't have enough time, and at that point one doesn't want to make time to study.]

Guadalupe describes similar reasoning for why making time to access English classes is a challenge:

G: "Si, una de las cosas es no tener mucho tiempo porque uno sale temprano a trabajar, y ya cuando regresa pues regresa cansada, lo que quieres llegar es acostarte a descansar un rato."

[G: Yes, one thing is not having a lot of time because you leave the house early to go to work, and when you get home, you get home tired, and all you want to do is lay down and rest for a bit.]

L: “¿Pero ademas de eso?”

[L: But besides that?]

G: “Además de eso, pues, bueno, para ir a una escuela de paga, pues, el dinero, porque aquí en la Roosevelt porque es bueno no se, si es gratuito, pues podemos ir a ver si tenemos el tiempo en los horarios que van, podremos ir, nos conviene." (Guadalupe, 219-225)

[G: Besides that, well, to go to a school where you have to pay, the money, because here at Roosevelt it's good, and it's free, so we can go if we have time and the schedule aligns with our schedule.]

These two barriers point to the benefit of employer-sponsored ESL education, because being able to allot sufficient time and money to learn English can be unattainable for fast-food workers who work long hours and arrive home tired, all the while earning minimum (or close to minimum) 
wage. Additionally, contextualized ESL requires a certain amount of input from both employers as well as employees in a restaurant, in order to determine what curriculum would most benefit the English learners in the context of current and future career opportunities in the field.

\section{Discussion}

Prior to completing my interviews, I had a number of preconceived notions:

1) I assumed that lack of English language skills would be a near-singular reason behind kitchen workers not moving up into management positions.

2) I assumed kitchen workers would be around quite a bit of English in their work day.

3) I assumed that the kitchen worker demographic would be diverse at the restaurant sites where my participants work

4) I assumed that the majority of kitchen workers would want to be in management positions

5) I assumed that there would be clear perks of being in a management position However, through the enlightening process of talking with people who have worked in fast-food restaurants for between 11 and 23 years, I found that all of my initial assumptions were an attempt to generalize about an environment and working dynamic that I have never experienced nor directly observed, and therefore largely incorrect. Each participant presented a unique experience and narrative, making it clear that each restaurant chain functions differently, and even varies franchise to franchise. Motivation is also highly variable among people, and what motivates one person can overwhelm another. Therefore, not everyone sees a linear employment path with upward mobility as the ultimate goal. Additionally, when I began this project I believed the idea that it is crucially important for restaurant employees, especially those who are immigrants, to have the opportunity to "increase [their] awareness of career ladders and the hourly wages associated with each step on the ladder" (Wrigley, 2015, p. 4). However, after speaking with my three participants, I now understand that an employee's understanding of the career ladder doesn't necessarily mean they will feel inclined to climb the ladder, for a variety of 
other external and internal reasons. For example, sometimes the pay difference between a line cook position and a managerial position doesn't adequately compensate for the increase in stress and responsibilities. This came up in both my conversations with Carla and Rosa.

\section{Conclusion}

Through my research I found that my participants' employment journeys and experiences are far more nuanced than I originally supposed. They do have clear similarities when it comes to facts such as the comparably long lengths of time they have worked in their respective fast-food restaurants prior to being offered a management position. Meanwhile, they also demonstrate unique differences in regard to the paths to management they have experienced and perceived, and their level of language confidence in the workplace. For two participants, they perceive management positions to be very stressful, while the third participant views a potential management position as exciting and interesting. All three cite a lack of outside time to devote to language study as a barrier between them and learning English, and have varying amounts of access to English language education; one of the participants has participated in an employer-sponsored English language program, while the other two participants have never had access to a similar opportunity. Related to a lack of time to devote to language study, all three participants cited work as the only space in which they consistently hear and speak English, shedding light on another aspect of the challenge they face incorporating English language learning into their lives. All three participants have been offered and have turned down management positions, citing a variety of reasons such as lack of language skills, lack of desire to change shift schedule, lack of adequate compensation for the managerial role, and fear of the stress this would cause in their daily life to have additional responsibilities as a manager. This 
suggests a mismatch between the perception the fast-food worker has of their own language skills, and their manager / supervisor's perception of their language skills and readiness to assume a managerial position. The mismatch points to a need for more English language education, which has the potential to bolster learner confidence and potentially lessen the gap between employee and manager/supervisor perception of the employee's language skills.

Because of the small sample size, my project serves more as a case study than example of information representative of any critical mass of experiences. As is evident in the data I gathered from the three participants, experiences in fast-food restaurants from the perspective of Latinx people working in the fast-food industry can be as varied as any other life experience; what scares one person can excite another. My study reflects the experiences of participants who work in Oregon and Washington; other fast-food workers in other states may have very different experiences. Finally, given that I met two out of three of the participants through my ESL teaching position, it is possible they shared information with me that they would be less comfortable sharing with a researcher whom they did not have previous rapport with.

To summarize my recommendations, first and foremost I recommend to fast-food restaurants that they invest in the English language skills of their employees by offering an employer-sponsored english language course, or partnering with a local organization to provide a course tailored to the needs of their employees. Second, I recommend that the course offered to fast-food workers be highly compatible with their schedules, offer childcare, and when funding allows, compensate them for their time equal to their ordinary hourly wage. The positive effects of English language learning for fast-food workers benefit the workers in their personal and professional lives, as well as the fast-food restaurants, in several ways. First, by offering English 
language classes, the fast-food restaurants can increase their ability to promote from within, and hire managers who have had experience working other positions at the restaurant. This has the potential to decrease turnover, as well as support the connection between line cooks and managers, thanks to the bilingual language capabilities of the managers. To elaborate, if an employee has the opportunity to improve their English language skills in an employer-sponsored or supported manner, they will be more likely to know how to give feedback to their supervisees, supervisors, and co-workers, and to communicate in customer interactions with clarity and efficiency.

In terms of specific language needs on which curriculums should focus their efforts, all three participants emphasized needing verbal skills. Possessing these skills which would enhance their ability to communicate with their co-workers, supervisors, supervisees, customers, and other people they need to be able to interact with at work. More specifically, participants voiced the desire to learn how to give both positive and corrective feedback, carry on a telephone conversation with a repair person in the event of a broken machine, talk with a customer to take their order, engage in small talk with co-workers, and have the framework and vocabulary to navigate situations involving conflict management and resolution. In sum, the three participants I interviewed are some of the most hardworking people I have ever met, and they along with their Latinx colleagues (as well as people of other nationalities) in the fast-food industry are worth investing in. They all shared with me their desire and hunger to learn and be able to connect with their environments in English; whether they have the desire to become a manager or remain as a line cook, it is clear that supporting them in learning English will improve our ability as a nation to honor each other's experiences and value the perseverance that immigrants embody as they 
make a life in a new homeland. While my research focused on language skills and not immigration, in this national moment of immigration crisis, detention, and deportation, it is impossible not to feel the need to mention all the people who have come here, and are still coming here, hoping to leave behind insecurity and poverty in order to find opportunity, safety, and a future in the U.S. May they be met with kindness, empathy, and grace. 


\section{Works Cited}

Adult Vocational Training. (2017, June 19). Retrieved November 12, 2018, from http://www.countyhealthrankings.org/take-action-to-improve-health/what-works-for-heal th/policies/adult-vocational-training

Allmendinger, J. (1989). Educational systems and labor market outcomes. European Sociological Review, 5(3), 231-250.

Aspen Institute. (2014). McDonald's English under the arches. Retrieved from http://www.aspeninstitute.org/policy-work/economic-opportunities/skills-americas-future / models-success/mcdonalds-english-under-arches

Belcher, D. (2009). What ESP is and can be: An introduction. In D. Belcher (ed.), English for Specific Purposes in Theory and Practice. 1-20. Ann Arbor, MI: University of Michigan Press.

Belcher, D. and Lukkarila, L. (2011) Identity in the ESP context: Putting the learner front and center in needs analysis. In D. Belcher, A. M. Johns, and B. Paltridge (eds.), New Directions in English for Specific Purposes Research. 73-93. Ann Arbor, MI: University of Michigan Press.

Corbin, J. M., \& Strauss, A. L. (2008). Basics of qualitative research: Techniques and procedures for developing grounded theory. Los Angeles, CA: Sage Publications.

Covert, Bryce. (2013, June 21). How Raising The Minimum Wage Is A Racial Justice Issue. Retrieved November 05, 2018, from https://thinkprogress.org/how-raising-the-minimum-wage-is-a-racial-justice-issue-e82bb1 $6 \mathrm{~b} 4 \mathrm{f} 30 /$

Cwach, M., Gravely, M.L., Educational Resources Information Center, \& Denver Public Schools, CO. (1997). More Water, Madam? An ESL Curriculum for Service Helpers in Full-Service and Fast-Food Restaurants. S.1.]: Distributed by ERIC Clearinghouse. Retrieved May 08, 2019, from https://eric.ed.gov/?id=ED426253

Dudley-Evans, T. and St John, M.J. (1998). Developments in English for Special Purposes: A Multi-Disciplinary Approach. Cambridge, MA: Cambridge University Press

Fleming, S. (2015). Lack of vocational education stifles social mobility. The Financial Times, p. 
4. Accessed 6 Nov. 2018.

Geertz, C. (1973) Thick description: Towards an interpretive theory of culture. In The Interpretation of Cultures: Selected Essays. 3-30. New York, NY: Basic Books.

Gerdes, C., \& Wilberschied, L. (2003). Workplace ESL: Effective Adaptations to Fill a Growing Need. TESOL Journal, 12(3), 41-45. doi:10.1002/j.1949-3533.2003.tb00142.x

Green, J., Schrock, G., \& Liu, J. (2015). Portland's Food Economy: Trends and Contributions (pp. 1-48, Rep.). Portland, OR: Portland State University.

Hutchinson, T. and Waters, A. (1987) English for Specific Purposes. A Learning-Centred Approach. Cambridge, MA: Cambridge University Press.

Hyland, K. (2006) English for Academic Purposes. London, UK: Routledge.

McDonald's Archways to Opportunity. (n.d.). Retrieved April 17, 2019, from http://www.archwaystoopportunity.com/english_under_the_arches.html

Number of McDonald's in North America 2017. (2019). Retrieved February 05, 2019, from https://www.statista.com/statistics/256040/mcdonalds-restaurants-in-north-america/

Paltridge, B., Harbon, L., Hirsch, D., Shen, H., Stevenson, M., Phakiti, A., and Woodrow, L. (2009) Teaching Academic Writing: An Introduction for Teachers of Second Language Writers. Ann Arbor, MI: University of Michigan Press.

Paltridge, B., \& Starfield, S. (2012). Introduction. In B. Paltridge \& S. Starfield (Eds.), The handbook of English for specific purposes (pp. 1-4). Chichester, West Sussex, UK:

Malden, Ma. : Wiley-Blackwell.

Parrish, B., \& Johnson, K. (2010, April). Promoting learner transitions to postsecondary education and work: Developing academic readiness skills from the beginning (CAELA Network Brief). Washington, DC: Center for Applied Linguistics. Retrieved from http://www.cal.org/ caelanetwork/resources/transitions.html

Reich, D., \& Cho, C. (2017, May 19). Unmet Needs and the Squeeze on Appropriations. Retrieved November 11, 2018, from https://www.cbpp.org/research/federal-budget/unmet-needs-and-the-squeeze-on-appropri Ations 
Swales, J. M. (1990). Genre analysis: English in academic and research settings. Cambridge, UK; New York, NY: Cambridge University Press.

Workforce Innovation and Opportunity Act, H.R. 803, 113th Cong. (2013-2014). Retrieved from

https://www.gpo.gov/fdsys/pkg/PLAW-113publ128/pdf/PLAW-113publ128.pdf

Wrigley, H. (2015). Preparing English Learners for Work and Career Pathways: Issue Brief. LINKS ESL Pro Issue Brief. Washington, DC: American Institutes for Research. Retrieved from https://lincs.ed.gov/sites/default/files/ELL_Context_Instruction_508.pdf

Wrigley, H. S., Richter, E., Martinson, K., Kubo, H., \& Strawn, J. (2003). The language of opportunity: Expanding employment prospects for adults with limited English skills. Washington, DC: Center for Law and Social Policy.

Zeidenberg, M., Cho, S.-W. \& Jenkins, D. (2010). Washington State's Integrated Basic Education and Skills Training Program (I-BEST): New evidence of effectiveness (CCRC Working Paper No. 20). New York, NY: Community College Research Center. 


\title{
Appendix A: Consent letters (Spanish \& English versions)
}

\author{
Proyecto de tesis: Carta de consentimiento
}

Título: Un análisis de situación actual y evaluación de necesidades de hispanohablantes nativos en la industria de comida rápida de Portland: un estudio de sus experiencias de empleo y necesidades lingüísticas relacionadas con el trabajo.

-Durante las entrevistas, Livia Lichtenstein-Hershman va a hacerle a usted preguntas sobre sus experiencias trabajando en su lugar de trabajo, y cómo se relaciona al idioma que usa usted.

-Livia Lichtenstein-Hershman es una estudiante en PSU, y será la única persona que le entrevistará.

-Livia Lichtenstein-Hershman utilizará un pequeño grabador de voz para capturar la grabación de la entrevista. La grabadora estará grabando durante todo el tiempo.

-La información en las grabaciones será utilizada para entender las experiencias de los trabajadores en su lugar de empleo, para informar sugerencias para materiales de inglés como segunda idioma. Esta información puede estar desarrollada para enseñar empleados en lugares de trabajo como dónde trabaja usted.

·Las grabaciones sólo serán escuchadas por Livia Lichtenstein-Hershman y su asesora, Kathryn Harris.

-Su nombre nunca será usado en los estudios escritos del proyecto. Nadie que utiliza la información del estudio sabrá su nombre o apellido.

·Nadie en su lugar de empleo sabrá si usted participa en el estudio o no.

-Si no te gusta la entrevista puedes irte en cualquier momento. No habrá ningún problema para usted si deja la entrevista.

-Usted puede optar por no contestar cualquiera pregunta que no desea contestar.

- No habrá ningún problema si decide usted no contestar cualquiera pregunta.

-La entrevista durará entre 30 minutos y una hora y media, y se sucederá en un lugar público.

·La participación en una entrevista indica el consentimiento para participar en este estudio.

Si usted tiene preguntas puede llamar Livia Lichtenstein-Hershman a 971-703-9910 o Kathryn Harris en la University Center Building, 527 SW Hall St. STE 301Y Portland, Or. 97201, (503)725-8300. También se puede llamar a la Junta de revisión institucional de la PSU en: Investigación de integridad, investigación y estudios de postgrado 1600 SW 4th Ave., Richard and Maurine Neuberger Center, Ste. 620

Portland, OR 97201 
(503) $725-2227$ or 1 (877) 480-4400

\section{Thesis Project: Consent Letter}

Title: A Present-Situation Analysis and Needs Assessment of Native Spanish Speakers in the Portland Fast-Food Industry: A Study of their Employment Journeys \& Job-Related Language Needs

-During the interviews, Livia Lichtenstein-Hershman will ask you questions about your experience working at [employer], and how this relates to the language that you use.

-Livia Lichtenstein-Hershman is a PSU student, and will be the only person interviewing you.

-Livia Lichtenstein-Hershman will use a small voice recorder to capture the recording of the interview. The recorder will be on (recording) all of the time.

-The information in the recordings will be used to understand the experience of workers at [employer], in order to inform the suggestions for teaching materials that can be created to help teach [employer] employees English.

-The recordings will only be listened to by Livia Lichtenstein-Hershman and her advisor, Kathryn Harris.

-Your name will never be used in the studies. No one who uses the study information will know your first or last name.

-No one at [employer] will know if you participate in the study or not.

-If you do not like the interview you can leave at any time. There will be no problem for you if you leave the interview.

-You can choose to not answer any questions you do not want to answer.

-There will be no problem if you decide not to answer any questions.

-The interview will last between 45 minutes to an hour and a half, and be held in a public location.

-Participation in an interview indicates consent to participate in this study.

If you have any questions you can call Livia Lichtenstein-Hershman at 971-703-9910 or Kathryn Harris at University Center Building, 527 SW Hall St. STE 301Y Portland, Or. 97201, (503)725-8300. You can also call PSU Institutional Review Board at:

Research Integrity, Research \& Graduate Studies

1600 SW 4th Ave., Richard and Maurine Neuberger Center, Ste. 620

Portland, OR 97201

(503) 725-2227 or 1 (877) 480-4400

This research is approved by the Human Subjects Research Review Committee, Office of Research Integrity, Research \& Graduate Studies, 1600 SW 4th Ave., Richard and Maurine Neuberger Center, Ste. 62, Portland, OR 97201 (503) $725-2227$ or 1 (877) 480-4400 


\section{Appendix B: Interview Questions (Spanish and English versions) \\ Interview Questions in Spanish (Interviewer's Version)}

Before the interview, the Co-PI will give the interviewee a written list of the interview questions in Spanish, to allow the interviewee to look them over and begin thinking about their answers. If the interviewee lacks the literacy skills to be able to read the questions in Spanish, then the interviewer will read the questions slowly and clearly, so that the interviewee can hear them and mull them over.

The Co-PI will be setting up the recorder and getting situated while this is happening. Then, the Co-PI will tell the interviewee the following background:

"I am going to ask you some questions, and you can take as long as you need to think about them before answering. You are welcome to skip any questions you'd like."

During the interview, the Co-PI will give appropriate responses (e.g. "uhhuh," "yes," nodding of the head, smiling, etc.

Before beginning the interview, the interviewer will say "are you ready? Do you need a few more minutes to think?"

Preguntas para trabajadores de la cocina:

Preguntas sobre las características personales:

1. ¿Cómo se llama usted?

2. Voy a usar un nombre falso cuando me refiero a usted en mi proyecto. ¿Qué nombre le gustaría que usaría?

3. ¿De dónde es usted?

4. ¿Qué idiomas habla usted?

Ahora voy a hacerle a usted unas preguntas sobre su trabajo en (empleador). Puede contarme una historia sobre cómo llegó a trabajar en (empleador) y su experiencia con puestos diferentes?

Possible prompts to elicit their story:

5. ¿Cuánto tiempo lleva usted trabajando en (empleador)?

6. ¿Ahora que es su posición/ puesto / rol de trabajo?

7. ¿Alguna vez su empleador le ofreció un rol diferente en su trabajo?

Possible prompts:

a. ¿Lo aceptó?

b. ¿Si no aceptó, por qué no?

c. ¿Cómo se sintió usted cuando empezó el/la rol nuevo / posición?

d. ¿Ahora cómo se siente en este rol en comparación con el último rol? 
e. ¿Está satisfecha usted con su posición en (empleador)?

Ahora voy a hacerle usted unas preguntas sobre los idiomas que usa en su trabajo:

8. Por favor, pensando en su dia. ¿Me puede contar sobre un día normal, o un día cotidiano? ¿Qué es la primera cosa que pasa o qué hace usted cuando llega al trabajo? ¿Y esto lo hace en español o inglés? ¿Y después qué pasa? Etc.

9. ¿Hay algo que ha mencionado que le gustaría poder hacer en ingles? (references points in their day to clarify to out specific situations; if they mentioned specific stations / tasks, what languages were they using for those situations?)

10. ¿Ha tenido usted alguna experiencia aprendiendo inglés, ya sea formal o informal?

a. ¿Dónde?, ¿Cuándo?, etc.

b. (if so) ¿Cuáles fueron sus motivaciones para aprender inglés?

c. (if not) ¿Por qué no? ¿Existen barreras específicas?

Preguntas semiestructuradas específicas del proyecto:

11. Cuénteme usted sobre la última vez que habló con un cliente. ¿Puede explicar las circunstancias? ¿Qué dijo usted? Qué dijo el cliente? En cuál idioma hablaron?

a. ¿Cómo se sintió?

b. (reference a specific point elicited from their answer to get clarification if necessary)

12. Cuénteme usted sobre la última vez que habló con su supervisor. ¿Puede explicar las circunstancias? ¿Qué dijo usted? ¿Qué dijo el supervisor? ¿En cuál idioma hablaron?

a. ¿Cómo se sintió?

b. (reference a specific point elicited from their answer to get clarification if necessary)

13. Si pudiera hacer más cosas de trabajo en inglés, ¿tendrías más opciones para puestos en [empleador?] ¿En cuáles posiciones te interesarían? (¿Cuál es la conexión entre el nivel de idioma y la capacidad de trabajar como gerente?)

Preguntas para gerentes:

Preguntas sobre las características personales:

1. ¿Cómo se llama usted?

2. Voy a usar un nombre falso cuando me refiero a usted en mi proyecto. ¿Qué nombre le gustaría que usaría?

3. ¿De dónde es usted?

4. ¿Qué idiomas habla usted?

Ahora voy a hacerle a usted unas preguntas sobre su trabajo en (empleador). Puede contarme una historia sobre cómo llegó a trabajar en (empleador) y su experiencia con puestos diferentes? 
Possible prompts to elicit their story:

14. ¿Cuánto tiempo lleva usted trabajando en (empleador)?

15. ¿Ahora que es su posición / puesto / rol de trabajo?

16. ¿Alguna vez su empleador le ofreció un rol diferente en su trabajo?

Possible prompts:

a. ¿Lo aceptó?

b. Si no aceptó, ¿por qué no?

c. ¿Cómo se sintió usted cuando empezó el/la rol nuevo / posición?

d. ¿Ahora cómo se siente en este rol en comparación con el último rol?

e. ¿Está satisfecha usted con su posición en (empleador)?

f. ¿Qué le hace un buen ajuste para esta posición?

Ahora voy a hacerle a usted unas preguntas sobre los idiomas que usa en su trabajo:

1. Por favor, pensando en su dia. ¿Me puede contar sobre un día normal, o un día cotidiano? ¿Qué es la primera cosa que pasa o qué hace usted cuando llega al trabajo? ¿Y esto lo hace en español o inglés? ¿Y después qué pasa? Etc.

2. ¿Hay algo que ha mencionado que le gustaría poder hacer en ingles? (references points in their day to clarify to out specific situations; if they mentioned specific stations / tasks, what languages were they using for those situations?)

3. ¿Hay algo que ha mencionado que le gustaría poder hacer en español (o algún otro idioma) para comunicarse mejor?

4. ¿Ha tenido usted alguna experiencia aprendiendo inglés, ya sea formal o informal?

a. ¿Dónde?, ¿Cuándo?, etc.

b. (if so) ¿Cuáles fueron sus motivaciones para aprender inglés?

c. (if not) ¿Por qué no? ¿Existen barreras específicas?

Preguntas semiestructuradas específicas del proyecto:

1. Cuénteme usted sobre la última vez que habló con un cliente. ¿Puede explicar las circunstancias? ¿Qué dijo usted? Qué dijo el cliente? En cuál idioma hablaron?

d. ¿Cómo se sintió?

e. (reference a specific point elicited from their answer to get clarification if necessary)

5. Cuénteme usted sobre la última vez que habló con un empleado de la cocina. ¿Puede explicar las circunstancias? ¿Qué dijo usted? ¿Qué dijo el empleado? ¿En cuál idioma hablaron?

a. ¿Cómo se sintió?

b. (reference a specific point elicited from their answer to get clarification if necessary)

6. Si pudiera hacer más cosas de trabajo en (inglés o español), ¿tendrías más opciones para puestos en [empleador?] ¿En cuáles posiciones te interesarían? (¿Cuál es la conexión entre el nivel de idioma y la capacidad de trabajar como gerente?) 
7. ¿Piensa usted que la habilidad de ser bilingual es importante para los empleados de la cocina? ¿Piensa que es importante para los gerentes como usted? ¿Hay cosas específicas que usted desea que la gente pueda hacer en inglés? ¿Español? 


\section{Interview Questions in English (Interviewer's Version)}

Before the interview, the Co-PI will give the interviewee a written list of the interview questions in Spanish, to allow the interviewee to look them over and begin thinking about their answers. If the interviewee lacks the literacy skills to be able to read the questions in Spanish, then the interviewer will read the questions slowly and clearly, so that the interviewee can hear them and mull them over.

The Co-PI will be setting up the recorder and getting situated while this is happening. Then, the Co-PI will tell the interviewee the following background:

"I am going to ask you some questions, and you can take as long as you need to think about them before answering. You are welcome to skip any questions you'd like."

During the interview, the Co-PI will give appropriate responses (e.g. "uhhuh," "yes," nodding of the head, smiling, etc.

Before beginning the interview, the interviewer will say "are you ready? Do you need a few more minutes to think?"

Questions for kitchen workers:

Warm-up questions:

1. What is your first name?

a. I'm going to use a fake name for you in my project. What name would you like me to pick?

2. Where are you from?

3. What languages do you speak?

Now I'm going to ask you about your work at [employer]. Can you tell me the story of how you came to work at [employer] and your experience with different positions?

Possible prompts to elicit their story:

4. How long have you worked at [employer]l?

5. What is your position?

6. Have you ever asked for or been offered a different position at [employer]? Possible prompts:

a. If so, did you accept the position?

b. If not, why not?

c. If yes, how did you feel when you first began the new position?

d. How do you feel now in this position compared to your last position?

7. Are you satisfied with your position at [employer]?

Now l'm going to ask you some questions about the languages that you use at work: 
8. Think about your day. Can you walk me through it? What do you do when you first get there? Is that happening in English or Spanish? What happens next? After that?

9. Is there anything you've mentioned that would you like to be able to do in English? (references points in their day to clarify to out specific situations; if they mentioned specific stations / tasks, what languages were they using for those situations?)

10. Have you had English language learning experiences, either informal or formal?

a. Where, when, etc.

b. (if so) What were your motivations in learning English?

c. (if not) Why not? Are there specific barriers?

Project-specific semi-structured questions:

11. Tell me about the last time you spoke with a customer. Can you describe the circumstances? What did you say? What did the customer say? What language was the interaction in?

a. How did you feel?

b. (reference a specific point elicited from their answer to get clarification if necessary)

12. Tell me about the last time you spoke with your manager. Can you describe the circumstances? What did you say? What did the manager say?

a. How did you feel?

b. (reference a specific point elicited from their answer to get clarification if necessary)

13. If you could do more job things in English, would you have more options for positions at [employer?] What positions would interest you? (What is the connection between language level and the ability to work as a manager?)

Questions for managers:

Warm-up questions:

1. What is your first name?

a. I'm going to use a fake name for you in my project. What name would you like me to pick?

2. Where are you from?

3. What languages do you speak?

Now I'm going to ask you about your work at [employer]. Can you tell me the story of how you came to work at [employer] and your experience with different positions?

Possible prompts to elicit their story:

4. How long have you worked at [employer]?

5. What is your position?

6. Have you ever asked for or been offered a different position at [employer]?

a. Possible prompts: 
i. If so, did you accept the position?

ii. If not, why not?

iii. If yes, how did you feel when you first began the new position?

iv. How do you feel now in this position compared to your last position?

v. What makes you a good fit for this position?

7. Are you satisfied with your position at [employer]?

Now l'm going to ask you some questions about the languages that you use at work:

8. Think about your day. Can you walk me through it? What do you do when you first get there? Is that happening in English or Spanish? What happens next? After that?

9. Is there anything you've mentioned that you would like to be able to do in English? (references points in their day to clarify to out specific situations)

10. Is there anything you've mentioned that you would like to be able to do in Spanish (or another language) to communicate more effectively?

11. Have you had English language learning experiences, either informal or formal?

a. Where, when, etc.

b. (if so) What were your motivations in learning English?

c. (if not) Why not? Are there specific barriers?

Project-specific semi-structured questions:

12. Tell me about the last time you spoke with a customer. Can you describe the circumstances? What did you say? What did the customer say? What language was the interaction in?

a. How did you feel?

b. (reference a specific point elicited from their answer to get clarification if necessary)

13. Tell me about the last time you spoke with a kitchen staff. Can you describe the circumstances? What did you say? What did the manager say?

a. How did you feel?

b. (reference a specific point elicited from their answer to get clarification if necessary)

14. If you could do more job things in [English or Spanish], would you have more options for positions at [employer?] What positions would interest you? (What is the connection between language level and the ability to work as a manager?) Is being bilingual important for you? Do you think being bilingual is important for kitchen staff? Are there specific things that you wish people could do in English? Spanish? 


\section{Interview Questions in Spanish: Interviewee's Version, for Kitchen Employees}

Preguntas sobre las características personales:

1. ¿Cómo se llama usted?

2. Voy a usar un nombre falso cuando me refiero a usted en mi proyecto. ¿Qué nombre le gustaría que usaría?

3. ¿De dónde es usted?

4. ¿Qué idiomas habla usted?

Ahora voy a hacerle a usted unas preguntas sobre su trabajo en (empleador). Puede contarme una historia sobre cómo llegó a trabajar en (empleador) y su experiencia con puestos diferentes?

5. ¿Cuánto tiempo lleva usted trabajando en (empleador)?

6. ¿Ahora que es su posición/ puesto / rol de trabajo?

7. ¿Alguna vez su empleador le ofreció un rol diferente en su trabajo? Possible prompts:

a. ¿Lo aceptó?

b. ¿Si no aceptó, por qué no?

c. ¿Cómo se sintió usted cuando empezó el/la rol nuevo / posición?

d. ¿Ahora cómo se siente en este rol en comparación con el último rol?

e. ¿Está satisfecha usted con su posición en (empleador)?

Ahora voy a hacerle a usted unas preguntas sobre los idiomas que usa en su trabajo:

8. Por favor, pensando en su dia. ¿Me puede contar sobre un día normal, o un día cotidiano? ¿Qué es la primera cosa que pasa o qué hace usted cuando llega al trabajo? ¿Y esto lo hace en español o inglés? ¿Y después qué pasa? Etc.

9. ¿Hay algo que ha mencionado que le gustaría poder hacer en ingles? (references points in their day to clarify to out specific situations; if they mentioned specific stations / tasks, what languages were they using for those situations?)

10. ¿Ha tenido usted alguna experiencia aprendiendo inglés, ya sea formal o informal?

a. ¿Dónde?, ¿Cuándo?, etc.

b. ¿Cuáles fueron sus motivaciones para aprender inglés?

c. ¿Por qué no? ¿Existen barreras específicas?

Preguntas semiestructuradas especificas del proyecto:

11. Cuénteme usted sobre la última vez que habló con un cliente. ¿Puede explicar las circunstancias? ¿Qué dijo usted? Qué dijo el cliente? En cuál idioma hablaron?

a. ¿Cómo se sintió?

12. Cuénteme usted sobre la última vez que habló con su supervisor. ¿Puede explicar las circunstancias? ¿Qué dijo usted? ¿Qué dijo el supervisor? ¿En cuál idioma hablaron?

a. ¿Cómo se sintió? 
13. Si pudiera hacer más cosas de trabajo en inglés, ¿tendrías más opciones para puestos en [empleador?] ¿En cuáles posiciones te interesarían? (¿Cuál es la conexión entre el nivel de idioma y la capacidad de trabajar como gerente?) 


\section{Interview Questions in Spanish: Interviewee's Version, for Managers}

Preguntas sobre las características personales:

1. ¿Cómo se llama usted?

2. Voy a usar un nombre falso cuando me refiero a usted en mi proyecto. ¿Qué nombre le gustaría que usaría?

3. ¿De dónde es usted?

4. ¿Qué idiomas habla usted?

Ahora voy a hacerle a usted unas preguntas sobre su trabajo en (empleador). Puede contarme una historia sobre cómo llegó a trabajar en (empleador) y su experiencia con puestos diferentes?

1. ¿Cuánto tiempo lleva usted trabajando en (empleador)?

2. ¿Ahora que es su posición / puesto / rol de trabajo?

3. ¿Alguna vez su empleador le ofreció un rol diferente en su trabajo? Possible prompts:

a. ¿Lo aceptó?

b. Si no aceptó, ¿por qué no?

c. ¿Cómo se sintió usted cuando empezó el/la rol nuevo / posición?

d. ¿Ahora cómo se siente en este rol en comparación con el último rol?

e. ¿Está satisfecha usted con su posición en (empleador)?

f. ¿Qué le hace un buen ajuste para esta posición?

Ahora voy a hacerle a usted unas preguntas sobre los idiomas que usa en su trabajo:

1. Por favor, pensando en su dia. ¿Me puede contar sobre un día normal, o un día cotidiano? ¿Qué es la primera cosa que pasa o qué hace usted cuando llega al trabajo? ¿Y esto lo hace en español o inglés? ¿Y después qué pasa? Etc.

2. ¿Hay algo que ha mencionado que le gustaría poder hacer en ingles? (references points in their day to clarify to out specific situations; if they mentioned specific stations / tasks, what languages were they using for those situations?)

3. ¿Hay algo que ha mencionado que le gustaría poder hacer en español (o algún otro idioma) para comunicarse mejor?

4. ¿Ha tenido usted alguna experiencia aprendiendo inglés, ya sea formal o informal?

a. ¿Dónde?, ¿Cuándo?, etc.

b. ¿Cuáles fueron sus motivaciones para aprender inglés?

c. ¿Por qué no? ¿Existen barreras específicas?

Preguntas semiestructuradas específicas del proyecto:

1. Cuénteme usted sobre la última vez que habló con un cliente. ¿Puede explicar las circunstancias? ¿Qué dijo usted? Qué dijo el cliente? En cuál idioma hablaron?

d. ¿Cómo se sintió? 
5. Cuénteme usted sobre la última vez que habló con un empleado de la cocina. ¿Puede explicar las circunstancias? ¿Qué dijo usted? ¿Qué dijo el empleado? ¿En cuál idioma hablaron?

\section{a. ¿Cómo se sintió?}

6. Si pudiera hacer más cosas de trabajo en (inglés o español), ¿tendrías más opciones para puestos en [empleador?] ¿En cuáles posiciones te interesarían? (¿Cuál es la conexión entre el nivel de idioma y la capacidad de trabajar como gerente?)

7. ¿Piensa usted que la habilidad de ser bilingual es importante para los empleados de la cocina? ¿Piensa que es importante para los gerentes como usted? ¿Hay cosas específicas que usted desea que la gente pueda hacer en inglés? ¿Español? 


\section{Appendix C: Interview Transcriptions with Themed Color Coding}

Key:

Theme 1: Specific English needs

Theme 2: Path to working in management that they have experienced or perceived

Theme 3: Factors that influence their confidence / ability / desire to learn and use English, including treatment?

Bold $=$ especially important

Note: I used the different fonts to distinguish who said what.

\section{Carla's Interview Transcription}

L: Como se llama usted?

C: $x x x x x x x x x$ [name removed for confidentiality]

L: Bueno. Y voy a usar un nombre falso cuando me refieroa usted en mi proyecto. Que nombre

le gustaría que usaría?

C: Carla

L: Carla? Bueno, Carla. De dónde es usted?

C: Mexico.

L: Y qué idiomas hablas?

C: Espanol.

L: Perfecto. Y Ingles, no?

C: (laughs) Y Ingles, muy poco

L: (laughs) Creo que más que un poco (both laugh). Ahora voy a hacerle a usted unas preguntas sobre el trabajo en Taco Bell y tambien Taco Time si quieres contestar sobre los dos, está bien, o si solo uno está bien también. Um, puede contarme una historia sobre cómo llegó a trabajar en Taco Bell / Taco Time?

C: Ehh... en el Taco Bell entre a trabajar en el año 1995, a través de una compañera, una amiga que sabía que necesitaban gente para trabajar, entonces fuimos una amiga y yo íbamos a meter una aplicación y por cierto dos semanas seguidas fuimos al diario, a las 10 de la mañana para que nos mirara la manager que necesitaba [ininteligible, but something referring to how the manager needed people to work there] entonces íbamos todos los días y este ahi nos desayunabamos, acabamos a desayunar, llegaba la manager a las 10:30, nos miraba, y ya regresabamos a la casa hasta que nos agarró, hasta que nos contrató

L: Muy bien! Wow!

C: Después de dos semanas [undecipherable], but referring to how it took them 2 weeks to get the jobs]

L: Siiii

C: Cuando llegaba la manager no más nos miraba y le daba risa, "otra vez?!" nos decía (both laugh)

C: Ya tardamos para entrar pero este de ahí estuve trabajando de 95 a 2008.

L: Wow.

C: Ah hah. Y ya este de ahí este hubo problemas ahí en el restaurant y pues nos este nos sacaron... a nosotros, a todos, los que estábamos trabajando por los de documentos. 


\section{L: Si. En Taco Time fue este?}

C: No, en Taco Bell.

L: Taco Bell. Ok.

C: De ahí estaba en este trabajo nada más este estaba bien, anteriormente me costaba más porque no me había tenido experiencia en un restaurant, pero cuando entra Taco Bell a Taco Time ahi me costó más porque el dueño se preocupaba por los empleados. El se preocupa, por lo menos cuando llegaba él y nos saluda, y si ve que uno está triste o que uno estaba callada nos preguntaba que teníamos, en que nos podía ayudar, y ahí donde estaba yo en el Taco Time, no había manager. Entonces, [ininteligible] todos hacíamos el trabajo, éramos dos personas cuando yo llegue al medio año el patron me dio tambien a mi la responsabilidad de contar el dinero que está en la caja fuerte?

\section{L: Mmmm hmmmm}

C: Entonces éramos dos personas los que contábamos ese dinero las que íbamos al banco y si algún problema había, a él le podría uno contar aunque no se mucho ingles, pero como él llegaba seguido uno o dos o tres veces se lo decía a yo hasta que me entendía. Ahh ha. Entonces, él dejaba ahí eso, contaba uno las cajas, contaba uno el dinero, y el decia que no había necesidad de que el nos miraba todo el tiempo atraz de uno y mirando las camaras si nosotros hacíamos bien el trabajo.

\section{L: Wow. Muy bien!}

C: Entonces ahí me gustaba mucho ahí con él, con ellos, porque eran un matrimonio, también la señora es muy buena, entonces el si siempre daba más como oportunidades hasta que el nos enseño a mi me enseño contar una caja, me enseño sacar reportes de su tienda, que cada semana se llevaba un control de todo le se vendió, todo eso, esas cosas nos enseñaron.

\section{L: Wow!}

C: Ahh hahh y a mi yo cuando entre era medio año en trabajando cuando me dijo que iba yo a empezar haceres. Eramos dos. Ah hah. Entonces, este, el siempre le decía pues que nos tenía mucha confianza a las que estábamos. Y también ha tenido otras, otros restaurantes, uno en Hillsboro, y lo cerró, y como tres empleadas se vinieron por acá. O sea que todo los que han tenido este trabajo por muchos años.
L: Ahh. Wow.
C: Y eso era ahí ya cuando cerró su restaurante dijo que lo iba a cerrar porque iba a hacer el edificio de ahi donde estaba, me pase otra vez en Taco Bell, y tal vez por la diferencia pues es la verdad que todavía no lo arranco acostumbrarme.

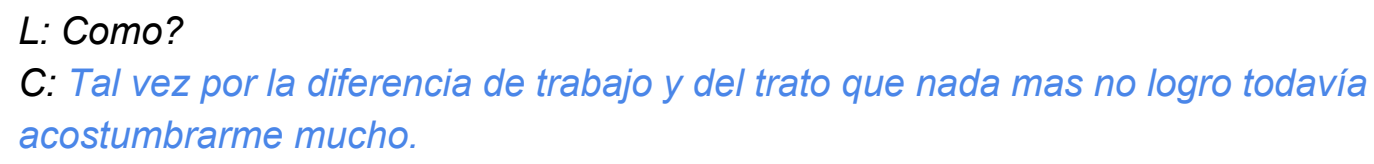

L: Ohhhh :( Entones, prefieres trabajar en Taco Time.

C: Si. Por, bueno en Taco Time y por el manager, el dueño que estuvo, el dueño porque también si fuera otro pues a la mejor no.

L: Exacto. Ahh, ok.

C: Ahh hahh. Pero quien este este si es de es diferente porque de antes si la manager si la que se salió apenas ella sí era muy especial. Ella...

\section{L: Especial significa algo mal?}


C: Si, ahh hah, sí algo mal en que si le caiste bien, estuvo que no vas a trabajar mucho, ella era de las que llegaba, se sentaba en la oficina o en la comedor, y tenia las que nos caía bien dos o tres, y las llamaba para que nos tenía que hablar con ellas entonces se sentó con esas empleadas como una hora, hora y media, y ya las que estábamos en la línea trabajando somos los que estamos trabajando más siempre...

L: Si

C: Ahh hah quizás esta por eso empezaron a bajar sus... lo que nos piden pues ahí en el restaurant es cierto tiempo para las órdenes, que la gente no hable que salió mal la comida o que no que o que estaban esperando por mucho tiempo o que ponen complaints y pues todo eso mucho con ella, entonces la mandaron a otra tienda, pero yo pienso que todo eso es como que tiene que ver con lo que hizo ella.

L: Ahhh. Y ella era de aquí de los EEUU?

C: Si, ella si,

L: Fue un poco... o como fue hablar con ella?

C: No, casi este no hablaba yo mucho con ella, ahh hah.

L: Si. Y ella hablo espanol tambien?

C: No. No ella no hable espanol.

L: Ahh, ok. Y qué piensa sobre eso, usted?

C: Que pienso? Pues, pienso siempre que es a veces pienso que también mucho racismo.

L: Si.

C: Entre ellos para nosotros, mas con los hispanos

L: Mmmhmm.

C: Ahh hahh. Porque ella también lo que puso que decidía que por ejemplo, que si ibas a faltar un mes antes que se le diera

L: Un mes es mucho!

C: Si, entonces si hablo nosotros dijimos a la otra muchacha que hablaba ingles y espanol que nos dijera que a veces para hacer una cita no es posible saber un mes antes la fecha, a veces menos. También ella siempre decía "a mi, no me importa - si no quieren trabajar, pues, no pueden." Entonces, siempre era eso. Pero le dijo a los que ella les caía bien, hay muchos muchachos tal vez porque son muchachos, no tienen la necesidad de que, pues un dia antes Ilaman, que no van a venir a trabajar, y no pasa nada.

L: Como? No entendi.

C: Hay veces que en cómo los muchachos de high school por ejemplo no pueden venir a trabajar. Tal vez es porque ellos como que no tienen la necesidad de trabajar, ellos si con un dia antes o en la noche hablan que no van a ir o si entran, por ejemplo si entran a las 9 y a las 8 hablan que no van a ir a trabajar, pues esta bien.

L: Pero esto no puede pasar con las más grandes?

C: Con las más grandes o con gente hispano, eso no puede pasar

L: Ahh! Entonces los chicos no son hispanos?

C: No. No son hispanos.

L: Ahh ok ahora veo la conexión 
C: Si, eso es pero esperamos el manager que entró [indecipherable but was saying she hopes the new manager is not like the old one with the unfair leave practices]

L: Si, porque si esto es discriminación.

C: Si.

L: Oy. Que mal. Umm, entonces en el Taco Time estabas desde...

C: En el Taco Bell, estuve el 95 al 2008. En el Taco Time, estuve de 2009 a 2017. En Taco Time.

L: Ah, entonces es muy nuevo el trabajo en Taco Bell. Entonces, solo llevas como un año?

C: Ano y medio, ahh hah

L: Y ahora como se llama su posición? En Taco Bell?

C: En Taco Bell, sigo ahí en la cocina.

L: En la cocina.

C: Si me han dicho a volver a decir otra vez está manager cuando se salió qué porque no era como... shift leader para... pero los dije que siento que necesita todavía más inglés,

L: Mmm hmm

C: Ahh hah. Porque en el Taco Time estaba más despacio y como que no me enredaba yo tanto. Pero aquí en Taco Bell, pues son muchas cosas, las personas tienen mucho para hacer.

L: Ahh. Y sigues tomando clases? Los clases han empezaron de nuevo?

C: Hoy empieza, apenas le dije a norma que me mandó un mensaje que yo no voy a ir, voy a empezar el miércoles.

L: Ahh bueno.

C: Ahh hah.

L: Recuerdas el chico que vino para mirar nuestra clase? Es el que va a enseñar la clase ahora.

C: Ahh. Y habla espanol?

L: Creo que habla algo de espanol, pero no se cuanto. Um, entonces, alguna vez su empleador le ofreció un rol diferente en su trabajo, pero...

C: Si, aqui en el Taco Bell, pero dije que no

$L: Y$ esto fue la primera vez? O ha pasado antes?

C: Ya me dijo ella, fue la que ya me dijo dos veces. La misma manager me dijo como tres semanas atrás, otra vez. Y porque no? Porque... y si lo que me dijo ella es que "yo quiero que seas shift leader para que tu apures a la gente para que trabajan mas rapida."

L: Para que la gente trabajan mas rapida??

C: Si, trabajar más rápido y sacar más órdenes de comida.

L: Ahh, ok ok.

C: Pero la dijo que no, que necesitaba yo mas ingles, y me dijo, pues, en ingles, que si estamos hablando en inglés ahora y nos entendimos, porque no? Pero cuando hay un problema y uno se olvida todo, y ya no puedo...

(both laugh)

L: A mi me pasa mucho esto, en Espanol.

C: Entonces cuando no estoy nerviosa o eso, si, puedo platicar un poco más pero si hay un problemo y mas si un cliente se enojó, me espanto y ya me salen las palabras.

L: Umm, ok, entonces ahora está satisfecha usted con su posición? O... 
C: Ehh, sí porque en la cocina se siento uno más bien que si estás atendiendo a los clientes, porque a veces son difíciles, y unos son muy groseras.

L: Ahh.

C: Como hoy un cliente que llegó el fue que dijo que como mira esta chaparrita de cocina... dice "oy, yo pensé que la gente que trabajaba para estar ahi dice tenía que estar más alta! (laughs)

L: Dijo esto a usted?!

C: A mi! Ah hah! Yo parece que no lo entendí, le digo "no se que quieres decir," y ya me fui.

L: Bien!

C: Y le dijo a la otra muchacha le dijo a la otra muchacha la otra que estaba... yo entre de mi break, entonces para entrar del break tiene uno que ponchar ahí en una computadora que tienen, y fue cuando dijo él "yo pensé dice que para estar ahi dice en la caja dice, necesitaban estar más altas! Y le dije, "oh sorry, no te entendi lo que me dijiste." Ya me fui, y después a la otra muchacha dijo que sí dice "porque te enojaste si era solo una broma?" Le dije una grosería en español ehh [indecipherable ] que él pensó que las que trabaj...... Bueno pues para trabajar ahí, que necesitamos estar más altas! Todo el mundo, altas o chaparritas, hacemos el mismo trabajo!

L: Si

C: Uno se acomoda estar trabajando las cosas

L: Pero ese comento no tenía ninguna conexión con su comida, con su experiencia?

C: No pues, estaba parado ahí cuando yo regrese de mi break y eso fue cuando me dije esto.

L: Dijo esto en ingles?

C: En ingles, ahh hah.

L: Y usted respondió en inglés también?

C: Ah hah, yo le dije en inglés que no le entendi. "Sorry, no te entendí."

L: Bien, creo que esto fue la mejor respuesta que puedes decir.

C: Ya me fui par-alla... diciendole una grosería en español. Y pues dijo la muchacha dice la otra muchacha, la otra que estaba tomando, dice que para que te enojaste dice si era solo una broma...

L: Si...

C: Digo pues "que broma [sarmienta?]"

L: Si, pues, son tus emociones, puedes sentir lo que quieres sentir, no necesitas el permiso de nadie. Umm, entonces pensando en tu dia, me puede contar sobre un dia normal, como que hace primero, y después...?

C: Ahh, entro a las 6 de la mañana, y me toca este poner todo la comida en a calentar y abrirle a la línea preperar la línea para que de 6-7 hago eso y a las 7 de la mañana tiene que estar abierto

L: $M m m ~ h m m ~$

C: Después de esa hora este ya tengo que empezar a hacer órdenes y tengo que preparar lo que [hagan faltas?].

L: Mmm hmm. 
C: Y [indecipherable ] todo lleva arroz, queso, jitomate, crema, la [indecipherable ] que se no se prepara no se corta no se pica nada porque toda ya llega picada, entonces uno solo abre la bolsa.

L: Wow. De donde viene toda picada?

C: De otras tiendas, bueno lo mandan por ejemplo jitomate lo manden en una cajita así, que ya viene picado.

L: Wow! No sabia!

C: Llegan como unas 6 cajas que uno caja trae 4 cartoncitos, todo de eso llevo conmigo, las cremas están en un contenedor hecha de cartón, ya no mas lo pone en una.... Una como pistola, le dicen, y ya de ahi como se va grabando ahí se va tirando. Es desechable así. El queso llega todo picado, todo todo ya está. Lo único que que yo hago cuando hago el pico de gallo el único ingrediente que pico es el cilantro... porque la cebolla todo ya seria mucho trabajo y mucho lo que se ocupa. Entonces nada es lo que ando llevando llevó las tortillas, tengo que llevar los tortillas, tengo que hacer.. Pero para eso tengo que estar haciendo turnes y llevando todo preparado, para que a las 9 de la mañana ya me voy a mi break de media hora, y ya tengo que dejar cocinado todo para el lunche, para que cuando yo regreso de mi break, ya saco lo de [indecipherable].

$L: Y$ hace todo eso sola? O hay otra gente haciendo las mismas cosas mientras... er...

C: Yo eso yo lo hago sola

L: Ahh ok

C: Y por eso hay otra persona y esa otra persona se dedique a ponerlo de que va lo que se enfrie, lo que se va en aceite [hace] otra persona

L: Ahh, ok.

C: Y esta la manager que está tomando órdenes y ella pues también haciendo sus cosas... cada quien tiene su rol de lo que va uno. Y ya para las 11 de mañana todos tenemos que estar ya haciendo los órdenes de la comida. Ya no preparar uno nada, tiene que estar todo preparado, debe de estar todos las cosas ahi para que ahí nada más se agarran.

L: Como los tacos ya armados y todo?

C: Y si, todo.

L: Wow!

C: A las 11 tiene que estar todo hecho, ahh hah.

L: Y como saben cuánto van a pedir la gente?

C: Ehh, porque la manager pues ya sabe que tantos se vende, entonces ya tienen ahí la lista de cuánto van a necesitar, y ya uno por ejemplo yo los primeras días pues no sabía yo la cantidad que iban a llevar [la gente], pero ya trabajando unas semanas, dos semanas, ya se daba uno cuenta y ya sabe cuánto vamos a necesitar, o ver la lista que tanto vamos a hacer. Lo que prepara uno es no más para hasta las 2, porque a las 2 se vuelva a llevar otra vez... no debe de estar por ejemplo mucho tiempo la lechuga y queso son 4 horas los que tienen que estar y a las 2 vuelva uno y lleva otro pozo.

L: Ahh si, por las regulaciones de salud, no?

$C$ : Ahh hah, por las reglas que tienen.

L: Oh ok. 
C: A preparar frijoles, lo mismo porque también el frijol la llega este... seco, en bolsitas, y nada mas se le pone agua bien caliente se pienten el frijol y listo.

L: No tienen que hervirlas por cómo unas horas?

C: No no

L: Que frijol magico!!

C: (laughs) Y el arroz, ese tambien lo mismo, es arroz precocido, en que se pone también con agua caliente y entre 5 minutos ya esta.

L: Wow!

C: Si, en el Taco Time si ponemos a cocinar los frijoles, ahi si era una olla grandote y salieron mas bueno porque no eran los precocinados... arroz también lo mismo, uno se hace ahí el arroz como fresca, está cocinando ahi... porque ahi si habia estufa porque aquí no hay estufa, aqui lo que hay son unas hoyas... unos maquinas asi con agua hirviendo, que hace 96 de caliente, y ahi es donde se va poniendo las cosas.

L: Wow! Que futuristico!

C: (laughs) Si en Taco Time, si hacemos todas ahí en Taco Time, si nos tocaba picar tomate, cebolla, lo único que llegaba picada era la lechuga y el queso... en Taco Time, era nosotros que hacemos más. Segun yo, la misma con la carne... en Taco Time, se preparaba la carne se ponía a cocer, la carne como se va usando. Y aqui no, aqui la carne viene también lo mismo cocida, solo hay que calentar de ahora, y ya está.

L: Wow!

C: Sabe mas buena la carne del Taco Time.

L: Por su puesto! Si. Ok.

C: Y sin hacerle promoción a Taco Time.

(both laugh)

L: Um, entonces para cada cosa que está haciendo en el dia, que, no se, que porcentaje está usando espanol o ingles? Como todo el tiempo español, o a veces inglés también?

C: Ehh, cuando me ponen en la caja, ingles, pero si estoy en la cocina, es espanol.

L: Y por cuántas horas más o menos está en la caja?

C: En la caja, un casi no como hoy no estuve ningún rato...

L: Nada?

C: Nada.

L: Entonces algunos días algo, y unos dias nada?

C: Ahh hah. Pero hoy estuvo un manager que habla nada mas que ingles, entonces ahí estuve hablando inglés con el. Con el manager.

L: Y esto es normal? Pasa mucho?

C: No, esto si es normal, pasa casi todos los días.

L: Y los además también hablan inglés con el manager? O...

C: Si.

L: Ok, entonces cada uno habla por su mismo.

C: Si, cada uno habla por sí mismo.

L: Ok, no hay alguien que como intérprete

C: No. 
L: Ok, bien. Umm, que más. Umm, hay algo que ha mencionado que le gustaría poder hacer en ingles?

C: Hay, pues, hablarlo... mas rápido.

L: Más rápido? Ok. Pero como, no se, algun um situación en que prefería hablar en inglés pero no tienen las palabras ahora? No se, no creo que me estoy explicando bien.

C: Ohhhh no pero que si, a veces hay situaciones como por ejemplo de esa de de esa me gustaría a veces como la muchacha como te digo que se sentaba que se llevaba unas ahi, esa hora si me gustaria saber mas ingles para decirle... pero pues como a ella le decía uno algo y ella decía "no me importa..." siempre fue así.

L: Wow. Hmmm. Um, y con los demás con quién trabaja usted, hay algo que le gustaría poder hacer en ingles con los además en la cocina? O todos hablan espanol?

C: Todos hablan espanol.

L: Todos?? Ok. Entonces...

C: Pero cuando entra alguien que habla en inglés que nos toca decirles cómo se prepara la la preparación, es cuando a veces sufro un poco más para decirles el tiempo, como cada cosa lleva su tiempo, o por ejemplo a veces los frijoles que se ponen y hasta 45 minutos están listos a veces es eso que se me dificulta en decirle 45 minutos estos y después ya se [indecipherable] pero les digo dos o tres veces hasta que me entiende.

(both laugh)

L: Y es posible marcar con un marcador y cinta en la cosa 45 minutos? O algo asi para hacerlo más fácil?

C: Y si, si esta tambien a veces lo ponen ahi pero si no está entonces digo yo. El primer dia no me entendieron pero segundo dia ya vamos bien.

L: Muy bien! Tal vez puede practicar esto en la clase de Inglés en Roosevelt, no? Los números?

C: Si.

L: Ha tenido usted alguna experiencia aprendiendo inglés, que sea formal o informal? Creo que ya se la respuesta a esa pregunta jaja

C: Si. Porque cuando entre a trabajar, trabajaba yo los sábados. Pero después me tocaba trabajar con la manager que le digo que sacaron de trabajar, y también trabajaba ahí la hermana. Su hermana. Entonces como eran dos hermanas y entre ellas dos como que ellas dos se decian quién era más que la otra. Entonces si una decía una cosa y la otra decía no hagas porque yo soy más que ella. O que no me hagas caso entonce había veces en que me regañaron, me regaño ella, le dije al manager general y le dije que no quería trabajar los sábados, y que me pusiera si podria otro dia martes que me remplacera, pero si no le digo que prefiero no estar con ella, por el mucho estrés. Ya no aguantaba yo, antes sí, pero ahora que estoy más grande le dijo. Dijo el, pues, esta bien, porque él dijo. Si le explique segun yo como que para que me expliques mejor, vamos a necesitar un interpreter. Y llamó a la muchacha que me fue a interpretar, y lo le decía pues como paso las cosas de ese dia le digo porque si digo lo anterior no tiene caso. Entonces el manager dijo que estaba bien, que no me iba a poner los sabados, solo tenia que terminar el schedule que ya estaba hecha y ya para la siguiente, no. Pero con eso, la con quien tuve problemas se enojó con quien me interpreto, también. Que me dijo que ella nunca pensó que se iba a ponerla de mi lado, digo es que solo me interpretaste, 
porque él quería saber lo que pasó. Si luego dicen pero prefiero que venga la otra muchacha para que sepa yo bien exactamente, porque tu me estas diciendo una cosa y ella me dice una cosa diferente, entonces ya fue eso, y no con eso se enojo la esta muchacha con lo que me interpreto, que se enojó porque nunca pensó que se iba a poner de mi lado, pero yo dije pues no pusiste de mi lado, solo fuiste mi interpreter.

L: Y la muchacha quien te interpreto todavía sigue trabajando ahí?

C: Si! Ella es manager tambien ahi. Ella es manager.

L: Entonces no tuvo problemas con su trabajo?

C: No ella se enojo ahí pero no más.

L: Umm, y piensa que existen barreras entre usted y la meta de aprender inglés? Y si...

C: Ayy hay un montón de barreras. Por ejemplo aunque estoy repitiendo la frase y luego cuando ya me voy a decir esa me hace olvidar cómo y la repito y la repito pero

L: Yo entiendo esa situación cien por ciento. Pero entonces existen barreras pero en su mente, para entender. Has trabajado en un lugar donde tienen un programa de idioma, como un programa para aprender inglés? Porque he escuchado que McDonalds, por ejemplo, tiene un programa que se llama English Under the Arches, y es como un programa de McDonalds propia que enseña inglés a sus empleados.

C: No, no se si hay algo en el Taco Bell pero pienso que no.

L: Y tampoco existe algunos recursos diferentes para los empleados del restaurant?

C: No, nada. Lo único que sé que hay es que dan ahí becas para los trabajadores que quieren, pueden meter una aplicación para que reciben una beca.

L: Wow! No sabia!

C: Para los estudiantes.

L: Ahh pero no para los que no son estudiantes. Y la beca es para estudiar en general, o es para estudiar inglés específicamente?

C: No, estudiar en general.

L: Ok. Entonces no hay nada para aprender inglés.

C: No. Eso, no.

L: Hmm. um, ok las últimas tres preguntas. Um, cuéntame usted sobre la última vez que hablo con un cliente? Puede explicar los circunstancias? Qué dijo usted, que dijo el cliente, en cual idioma hablaron, no se si si puede pensar en una situación um además de la situación con el hombre de hoy, no se esto funciona para la respuesta.

C: Si, esta fue el último cliente con quien hable. Oh pues la última vez fue cuando se descompuso la freidora, y tuve que decir al cliente que no había chalupas, esta numero 6, que va con chalupas, y las chalupas son fritas. La freidora no servía y pues tenia que decir al cliente que no había chalupas que si lo queria cambiar por gorditas y pues ella estaba bien, no había problema.

L: Ahh bien!

C: Ahh hah. Esa fue bien, porque muy pocas veces salen clientas así que no se enojen, porque hay unas que se enojan y qye dicen que no que que no quieren recibir un cambio, y porque no podemos darles la comida de que ellos quieren.

L: Wow. Ok. Personas con vidas difíciles si andan así en la vida. Y cuéntame usted sobre la última vez que hablo con un supervisor? Puedes describir las circunstancias? 
C: Tres semanas anteriores que me estaba diciendo que fuera yo... que si porque no era shift leader para que la ayudara. No tienen ahorita manager, no tienen dos... y dice ella que estaba trabajando mucho, que no había la otra manager, y porque no me esté hago shift leader, pero el hacerse también shift leader significaria que ya lo cambian de turno porque la que está en la mañana siempre ha tenido su turno en la mañana. Entonces sería cambiarme turno a la noche, o los sábados y domingos, y yo cuando entré aquí el año pasado fue cuando pedí sábados y domingos para descansar, todo la vida los trabaje como mis niños estaban chiquitos, entonces era más fácil tener mi esposo con los hijos durante el dia, y yo iba a trabajar en la mañana casi... Ios días era cuando lograba yo hacer unas turnos solas, porque como faltan mucho entonces les sirviera de trabajar desde las 9-5 era mis horarios. Pero había veces en que trabaje 9-8, o 9-9, para sábados y domingos.

L: 12 horas??

C:12 horas, ahh hahh. Para completar los 40 porque en la semana mi horario era de 3-11, pero como si estaba lento, nos sacaba más temprano, hasta las 90 algo. Por eso los sábados y domingos a veces quede hasta las 8 o 9 para que lograba yo completar mis 40 horas. Pero ahora que estan grandes mis hijos, ya me dije cuando se cerraron Taco Time y me regrese aqui, dije que no importa que sea menos horas pero que no quería trabajar los sábados y domingos. Y esa vez fue la última vez que hable con ella que me dijo que por que no hace era yo ser shift leader pero le digo que seria cambiar el horario, trabajar en la tarde, y si trabajar sábado y domingo por lo que me dijo ella. Que si aceptaba yo trabajaria los sábados y domingos. Ahh hah.

L: Entonces no fue solo la falta de inglés, había más razones.

C: También los horarios.

L: Umm, y cuando estaba hablando con el supervisor estaban hablando en inglés?

C: En ingles, si, porque ella no habla espanol.

L: Si, ok. Y puderion entendernos?

C: Pues sí, porque me dijo ella que me entendió.

L: Si? Que bueno! Umm, ok, y cómo siente usted cuando está hablando en inglés?

C: Pues, siento bien, (laughs), siento bien cuando ya termina la conversación y me dicen que si me entendieron.

(both laugh)

L: Y última pregunta: Si pudiera hacer más cosas de trabajo en inglés, piensa que tendrás más opciones para puestos en Taco Bell y sí, en cuáles posiciones le interesaría trabajar?

C: Sí, si pudiera hablar más inglés si tendría yo la posibilidad de manager, asi ahh hah.

L: Y te interesa o... [este rol] viene con más responsabilidades no? Qué piensa sobre eso?

C: Si, que no me gusta

L: Por que?

C: Quien sabe, pero no me gustare. Yo veo que luego se estresan mucho. Es mucho trabajo, es que les exigen mucho en el tiempo, que es cierto como por ejemplo no deben de tardar más que 40 segundos para agarrar una orden. Y la comida para salir debe estar en el lunche a 55 segundos ya debe de salir, porque si pasa más tiempo suena una campanita, normalmente anda verde, pero cuando llegan 55 segundos se pone rojo y se hace así y todo eso cuenta. Es mucha estrés. Muy rapido, muy rapido. 
L: Mucha estres! No sabia!

C: No si, muy rapido. Por eso luego siempre dejan las órdenes del comedor pues esas si llevan más tiempo, pero con las del tray tienen que ser más rápido. Lo mismo para tomar una orden, debe estar tomando la orden rápido, rápido, te confirman que ya tomé yo las ordenes cuando no hay nadie ahí, entonces si no hay ni modo que otro queda, si no yo no me pongo... Es eso que tienen y este mas de esto y que les cuentan mucho luego los llamadas cuando llama un cliente para quedarse les bajan puntos, la misma si no está saliendo a tiempo la comida le bajan puntos, si tiene un número rojo significa que tienen un porcentaje de [bad marks as a manager... on their way to getting fired].

L: Y qué pasa si reciben muchos puntos así? Reciben menos sueldo o algo asi? O cómo los afecta?

C: Por ejemplo, la manager de antes a eso la afectó mucho porque no estaba muy bien sus números y por eso la cambiaron a trabajar en otra tienda, donde no está manager general, porque la bajaron a asistente.

L: Para aprender de nuevo su rol?

C: Ah hah.

L: Y cuanto más ganan los shift leaders que la gente que están trabajando en la cocina?

Sabes?

C: Pues, no mucho, creo que nada les dan como un dólar más

L: Entonces no tiene mucho sentido [ser manager]

C: No tiene mucho sentido porque hay si esto una vez paso un problema de una muchacha que, las dos hicieron managers, y estaba enojada porque a una le diera \$13, y a la otra \$13.50. L: Woah. Entonces dos shift managers pero ganaron diferentes sueldos? Y los dos eran de los estados unidos?

C: Son de acá, los dos. Pero si una se enojó porque a una le había dado más que la otra. Que se enteró hasta que nos enteró que iba a dejar a trabajar ahí y ya había puesta su carta porque iba a salir porque no pudo hablar con la manager, porque una estaba ganando más que la otra, y la otra faltaba mucho, tenía dos niñitos y tenía turnos de la noche y [indecipherable] y dijo ella que cuando no vino la otra muchacha, yo tenía que trabajar más. Parece que sí, llegaron a un acuerdo, entonces no es mucho para tanto estrés y el tanto que les exigen.

L: Hmm hmm. Umm, creo que esto es todo! Muchas gracias! 


\section{Guadalupe's Interview Transcription}

L: Como se llama usted?

G: Xxxxxxxxxx [name removed for confidentiality]

L: Voy a usar un nombre falso cuando refiero a usted en mi proyecto, entonces qué nombre le gustaría que usará?

G: Lo que quiere poner

L: Bueno, si piensa de un nombre luego, avisame.

G: OK

L: De dónde es usted?

G: De Mexico

L: Que idiomas habla?

G: Solo espanol

L: Bueno. Ahora voy a hacerle a usted unas preguntas sobre su trabajo en McDonalds.

Puede contarme una historia sobre cómo llegó a trabajar en McDonalds, y su experiencia con los puestos que ha tenido si ha tenido más que un puesto?

G: Fui a dejar una aplicación a restaurant, y avisando que yo no sabía nada de trabajo de restaurantes, y me aceptaron, y ahí me enseñaron a preparar las cosas y había más trabajadores managers que hablaban español, y entonces no fue ningún problema para mi, aprender hacer las cosas. Porque muchas personas de los que estaban ahi trabajando hablaban espanol.

L: Ahh ok. Y esto fue hace... cuantos años?

G: Hace 15 anos, tengo mucho trabajando ahí.

L: Ah no sabia! 15 años trabajando en lo mismo McDonald's!

G: Si.

L: Y hay otras personas que han estado trabajando ahi por mas tiempo que 15 años? O...

G: Ehh, somos tres personas que hemos... que tenemos mucho tiempo ahí.

L: Wow, ok. Y ahora que es su position on rol de trabajo? Como se llama?

G: Ahora, estoy este mas tiempo haciendo hamburguesas.

L: Mmm hmm, ok. Y alguna vez su empleador le ofreció un rol diferente en su trabajo?

G: Si.

L: Si? De que?

G: De manager.

L: Ahh ok, y esto fue cuando?

G: Ehh, hace como cuatro años, ehh me dijo un manager que yo sabia preparar cosas, y sabía todo todo los... que yo sabía hacer las hamburguesas que yo sabía preparar la comida, que yo podía tomar el puesto de manager, pero yo lo dije que no, que yo no sé inglés.

$L: Y$ que dijo a eso?

G: El dijo que estaba bien, que yo podía tomarlo porque yo si sabia hacer las cosas, y yo dije que no.

L: Porque no sentia comoda? 
G: No, porque cuando llega el dueño, entonces ahí los managers ya hablan con él cuando hay alguna situación que hay que arreglar algo, y los managers tienen que hablar con el dueño.

L: Y pensando en este situation...

G: Pensando en esa situación, dije que no, pero si ya una vez me dijeron.

$\mathrm{L}: \mathrm{Si}$, ok. Porque se pone un poco nerviosa?

G: Si.

L: Ok. Y esto fue la última vez que el manager sugurio eso?

G: Si.

L: Está satisfecha usted con su posición de ahora?

G: Mmmm, si, estoy satisfecha...

L: Queria anadir mas?

(both laugh)

G: Si estoy contenta pero a la vez no porque también cómo no se ingles si podria yo tomar órdenes, si supiera ingles.

L: Ok. Umm, entonces ahora voy a hacerle a usted unas preguntas sobre los idiomas que usa en su trabajo, entonces pensando en su dia, me puede contar sobre un dia normal, como que es la primera cosa que pasa, y está usando ingles o espanol?

G: Ohh, lo primera cuando llega uno es es ver este cuántos empleados hay, para ver cómo nos vamos a tomar cada quien nuestra position. Si falta un empleado, los que estamos tenemos que cubrir ese espacio de ese empleado. Entonces es lo primero que vemos, como estamos. Y ya de ahi pues ya empezamos cada uno a hacer su trabajo.

$L$ : Entonces cada dia es diferente, nunca se sabe antes que llega cuanta gente van a llegar? Oy! Que dificil!

G: Si. El manager hace su sketch de sus empleados para estar allí cubriendo cada lugar. Pero a veces surgen emergencias y algún empleado llama al instante que no va. A veces alguien le llaman de emergencia que si tienen que ir y aunque estén llamando personas que vayan a trabajar, muchas veces no pueden. Entonce, ahi es donde nosotros nos ayudamos.

L: Ok. Huh! Umm, entonces además de hacer las hamburguesas, que otras cosas hace en el dia?

G: Por ejemplo, ehh, un dia normal para mi es... llegó en la mañana y esta una persona trabajando ya, haciendo los sándwiches porque son diferentes en la manada y diferentes en el lunche.

L: Ahh porque el menú de desayuno es diferente que lo del lunche?

G: Ahh hah, el menú de temprano es breakfast, después de las 10:30 ya es lunche, ya cambia Entonces hay una persona ya que ya está, tiene poquito de cada cosa, y ya cuando yo llego a las 7 de la manana, empiezo a poner un poquito más, porque ya van llegando más clientes, entonces hay que llenar un poquito más los gabinetes de cada producto que se va cocinando. Vas viendo la hora del día, hay que ir poniendo mas mas porque se esta poniendo mas ocupando a partir de las 10:30 ahi hay que llenar mucho porque ya están muchos clientes, y ahí ya van llegando más empleados, una persona está cocinando, tenemos una parrilla, una persona está cocinando, otra persona está haciendo 
hamburguesas, empezando a preparar los sandwich, otra persona está envolviendo para entregar la comida.

L: La gente que trabajan con usted en la cocina hablan español? Oh hay una mezcla?

G: Hay una mezcla. En la cocina regularmente somos puros hispanos. Puro espanol. Los managers hablan inglés. Son Americanos, la mayoría. Hay muchos managers; son como 10 yo creo. Es que la tienda es grande.

L: Wow! Ok, y cuántos de los 10 hablan espanol?

G: Yo creo que nada más uno.

L: Wow, ok.

G: Ahh hah.

L: Entonces 10 por ciento de la población de managers.

G: Por eso es que le digo cuando yo entré a trabajar la mayoria de managers hablaban espanol. Con el tiempo han ido cambiando entonces la mayoría ahora hablan inglés. Pero, con el tiempo, yo he ido aprendiendo ciertas poco a poco alguna palabra o alguna cosa y eso es lo que ha ayudado a mi a entender a ellos y ellos me entienden a mi. Aún que no sepas hablar ingles, perfectamente, pero si te falta una cosa, ehh, voy les digo no tenemos lechuga, nos falta lechuga, y ellos si me entienden que falta lechuga. $O$ falta cajitas para envoltura. $Y$ ellos entienden lo poco que yo se, me entienden. Eso ha sido cómo al transcurso de todo el tiempo que he ido aprendiendo poco a poco algunas cosas.

L: Que piensa que es la razón por que los managers han cambiado a casi puros estados unidenses?

\section{G: Antes no, los managers que había antes eran mas, la mayoria eran hispanos, pero pues les ofrecieron nuevos puestos, nuevos trabajos, y lógicamente que ellos agarran donde les pagan más.}

L: No se como ahora con la diferencia de gobierno, si hay menos gente viniendo ahora desde otros lugares para trabajar aca en los restaurantes por ejemplo.

G: Si, es cierto. Hmm hmm.

L: Entonces, cuantos minutos piensa más o menos pasa hablando en inglés en su dia?

G: En mi dia, es poco el tiempo que hablo inglés.

L: Ok, como solo cuando necesita algo de un manager?

G: Si, solo cuando necesito algo, solo cuando necesito este que me de me break

L: Tiene que preguntar cada vez que necesita un break?

G: No, no, ellos nos dan nuestro break pero si alguna vez ellos lo marcaron y no nos han dado yo voy y digo "oye me falta mi break" y dicen "oh esta bien disculpa, vete a tu break."

Pero ellos llevan un rol que nos va mandando, pero algunas veces son mucho los empleados entonces se les pasa. Pero tu vas y le dices "ya me falta" y dice "oh está bien, vete"

L: Muy bien. Entonces hay algo que ha mencionado que le gustaría poder hacen en inglés?

G: Oh si, me gustaria ser manager.

L: Si?

G: Si.

L: Bueno. Y qué ventajas tiene el rol de manager? 
G: Ehh, la ventaja de ahí de los managers es este una que no trabajan mucho en la cocina porque trabajar en la cocina es un poco más pesado que estar tomando ordenes. Porque está uno en una temperatura, las parrillas están muy calientes, la temperatura esta uff muy caliente y tener mucho cuidado de no quemarse los manos. Tiene uno de tener mucho precaución ahí, para trabajar. Uno tiene que tener cuidado, por eso cuando uno está trabajando con la parrilla tiene que estar más concentrada que cuando estás aquí haciendo hamburguesas porque la parrilla está una temperatura muy caliente, para que la comida salga caliente y rápida.

L: Hay algo además de ser manager que le gustaría poder hacer en ingles? Como un proceso, o tipo de interacción?

G: No pues, solamente me gustaría eso porque también está uno tomando órdenes al estar tomando órdenes como ahi mas este espacios de platicar con los clientes, no platicar pero si "hola, como estas, etc." menos estrés. Ah hah.

L: Entonces le gustaria hablar con los clientes! Muy bien!

G: Para tener mas platica ahi.

L: Si.

G: Oh ya una vez me dijeron si yo quería tomar ordenes tambien porque lo poquito que lo sé para ellos dicen que funciona porque cuando tu entras a trabajar ahí no sabes ingles lo primero es ponerte en la parrilla a cocinar, es la primero que entras. Ya cuando pasa el tiempo, y ya vas mirando aprender las computadoras, todo las claves de las hamburguesas, entonces ya pasas a hacer hamburguesas.

L: Ahh, ok. Y para la pregunta "ha tenido usted alguna experiencia aprendiendo inglés, ya sea formal o informal", además de la clase que yo enseñé hace unas meses, ha ido a otras clases?

G: No, no he ido a otras clases, pero si este me... cuando escucho a personas hablar ahí, le pregunto "puede repetir eso que dijiste? Que quiere decir?" Y ya me dicen que quiere decir.

L: A los otros empleados? O clientes?

G: Empleados. Alguna empleada habla espanol y ingles, hay algunas personas que te repite lo que están diciendo y lo que quieren decir. Me ha servido porque asi aprendo mas a leer la computadora cuando está saliendo la comida que ordenan, y aprendo allá hacer las bebidas, que muchas personas ahi les no quieren aprender, pero yo si.

L: Sabe porque no quieren aprender hacer las bebidas? Son difíciles?

G: Oh porque no son difíciles pero por lo mismo, hay que estar viendo la pantalla, las claves, y como es en ingles, se les dificulta.

L: Las claves como aparecen? Como numeros nada mas?

G: Si, una de las coasa que debe aprender ahí en un restaurante es que está uno, dos, tres, cuatro, por números, entonces si dicen "quiero un numero 1" entonces tenes que aprender qué es un número uno "oh es un Big Mac" y empiezas rápido. Pues un número dos pero en las bebidas no porque en las bebidas no mas van con puras iniciales, de la bebida por ejemplo un frappe o un capuccino como hay que aprenderse más las claves de las bebidas porque alguna quiere extra caramelo, alguna quiere caramelo y moka, uno quiere vanilla, y son no viene todo, no parece todo, las claves es lo que nosotros tenemos que aprender y 
eso si me gusto a mi. "Quieres venir a ayudar?" "Mmmm, si si voy." Porque ya con el paso de tiempo, uno o yo aprende a leer la computadora.

$\mathrm{L}: Y$ el hecho de hacer cosas nuevas hace el trabajo más interesante, no?

G: Y si, a mi me ayuda mucho eso porque como le digo estar en la cocina es más cansado, entonces si dice "alguien quiere venir a ayudar?" yo digo "sí!" y me voy porque me sirvo y voy. Y ayudó y aprendo más cada cosa.

L: Entonces hay una ocasión en que tiene que estar tomando los órdenes si falta un manager por ejemplo?

G: No, de tomar órdenes no, pero si de embolsar la comida por ejemplo, falta una persona ahí hoy en la cocina estamos completos. Pero alli en frente, hay una persona que está tomando órdenes, y porque es servicio del comedor, pero ve que hay ventanilla, drive through, entonces hay dos personas nada mas, uno esta por el servicio del mostrador, y otra está tomando órdenes aqui entonces falta una persona que les ayude a poner la comida en las bolsas. Y eso es donde yo si puedo ayudar porque voy y ya me pongo a leer "a aquí quiere cuatro muffin", meto, pongo cuatro a la bolsa, cuatro hashbrown, dos cafés, y ya le pongo su bolsita y está ahí. Eso es lo que yo puedo ayudar y eso es lo que me ayuda ahí, y me sirve de no estar en la cocina mucho tiempo.

L: Cuantos horas dura el dia de trabajo?

G: Regularmente son 8 horas, desde 7-3:00, 3:30

L: Solo lunes a jueves?

G: Domingo a jueves

L: Entonces antes de venir a la clase de inglés que enseñe hace unas meses, nunca a ido a otras clases ahi en Roosevelt?

G: No, si ya tiene como tres años que quise ir a una clase así, pero la maestra no hablaba español, entonces me dificulto muchísimo.

L: Y como supiera que había una maestra que habla espanol?

G: Yo le platique con mi hermana "Me gustaria aprender ingles" pero no entiendo porque la maestra habla pura inglés" y ella me dijo "oh la maestra habla espanol" y dije "voy a ir porque asi puedo expresar!"

L: Ahh que bueno! No sabía que yo fue la primera maestra que habla espanol.

G: No se, esto fue la primera vez que yo voy asi regularmente los maestros son americanos que no hablan espanol.

L: Creo que ahora el maestro nuevo habla un poquito de espanol.

G: Pero si es como usted estuvo bien porque nos explicaba bien que quiere decir en español, y porque no se puede decir o porque se debe decir, las maneras que uno puede hablar.

L: Me alegro de escuchar eso. Cuales fueron sus motivaciones para aprender inglés? Tal vez son obvios que ya quiere ser manager, pero hay algo además de eso que quiere añadir sobre las motivaciones de aprender inglés?

G: Pues uno de las motivaciones que uno le gustaría saber inglés es precisamente para entender todo lo que se habla lo que hablan, pues. Porque vas a una tienda y no entienda lo que están diciendo. Vas en autobús, porque yo viajo en bus, y tampoco no entiendes lo que está diciendo la persona que está junto a ti. 
$L:$ A veces son gente quien no se puede entender en cualquier idioma, pero a veces son gente que quieren platicar nada más.

G: Si, por eso.

L: Queria saber si además del trabajo, pasa usted mucho tiempo en lugares donde la gente están hablando ingles?

G: No, el trabajo es el único lugar.

L: Entonces esto se hace aún más difícil la meta de aprender inglés. Piensa que existen barreras específicas entre usted y la meta de aprender inglés? Cómo nose, cualquier tipo de barrera, como la falta de tiempo, o no se que.

G: Si, una de las cosas es no tener mucho tiempo porque uno sale temprano a trabajar, y ya cuando regresa pues regresa cansada, lo que quieres llegar es acostarte a descansar un rato.

L: Pero ademas de eso?

G: Además de eso, pues, bueno, para ir a una escuela de paga, pues, el dinero, porque aquí en la Roosevelt porque es bueno no se, si es gratuito, pues podemos ir a ver si tenemos el tiempo en los horarios que van, podremos ir, nos conviene.

L: Una pregunta porque trabaja en McDonalds, he escuchado que McDonalds tiene un programa que se llama English Under the Arches, como inglés bajo los arcos, que es un programa en línea creo, especificamente para los empleados de McDonalds, para aprender inglés. No se si ha escuchado algo de este programa?

G: Oh es que eso no no he escuchado nada de ese programa. No.

L: Porque hice un poco de investigación, lei en línea que para hacer este programa, tiene que ser como nominado por el manager como el manager va a decir quien de sus empleados seria no se, un buen estudiante para aprender inglés en este programa, pero creo que puede ser que en muchos restaurantes que los managers tampoco saben del programa, entonces ellos no pueden decir "ah tengo un empleado que quiere aprender inglés" porque no saben nada del programa!

G: No nos han dicho nada a nosotros

L: Esto es como no se, solo una cosa en que estaba pensando que tal vez puede funcionar para usted.

G: Si, voy a preguntar.

L: No se seguramente si todavia anda el programa, pero...

G: Ohh que bueno que me dijo, voy a preguntar.

L: Sí, porque sería como otra opción gratis que puede hacer aquí en su casa, pero no se le gustaria hacer el aprendizaje en línea, no se si suena como una buena idea. Pero puede ser buena idea! Las últimas tres preguntas: cuéntame usted sobre la última vez que hablo con un cliente, puede explicar las circunstancias? No se si esta pregunta tiene sentido en su caso porque no habla con muchas clientes, pero...

G: No, nosotros no hablamos con clientes, no.

L: Nada, ok. Entonces cuando está entregando la comida a los clientes en las bolsas a veces pasa algo en que tiene que responder directamente al cliente en inglés? 
G: Algunas veces que yo ha ido a ayudar a entregar la comida, pero ya es nada mas entrego de la comida, solo si les falta azúcar, o alguna salsa, es cuando ellos te dicen que les faltan un paquetito mas de azucar, salsa... eso sí entiendo.

L: Y como se siente cuando está hablando con un cliente?

G: Ohhh, lo que pasa es que nosotros los hispanos hablamos con las personas cuando hablamos con las personas que saben, los Americanos se puede decir, y hablan inglés ellos si nos entienden o no nos hace sentir mal que no lo expresamos bien, entonces uno se siente bien porque no están riendo de la persona que está hablando, aunque no le exprese bien, pero no se ríen de ti, uno se siente bien con eso. Entregas la comida, y decirle ahí está su comida, gracias, me siento bien en eso porque ellos no se rien de nosotros.

L: Así es como deberia hacer! Cuéntame usted sobre la última vez que hablo con un supervisor?

G: Pues, yo me siento bien porque lo poquito que yo se que he aprendido ahí en el trabajo este ellos me entienden, y alguna cosa que falta las señoras que están allí me dice doña, le puede decir que nos falta una cuchara para servir la salsa o algo, y ya voy, y le pido, pero los managers no hablan espanol, pero si entienden cuando yo les estoy pidiendo una cosa en dos palabras, dos palabras en ingles, y pues como ya me entienden, pues ya me siento bien.

L: Entonces no ha experimentado situaciones en que siente frustración o que se tratan los empleados que hablan solamente español diferentes que los que hablan inglés?

G: No.

L: Bien.

G: No, porque ahí nos trata... bueno, el idioma no ha se ve a ver a uno que nos trata mal ellos por el idioma ellos nos hablan si el como el manager no habla español, cuando quiere decir algo a los empleados que no hablamos inglés, entonces llama una persona que habla ingles y español, para que nos traduzca.

L: Es como debe ser!

G: Es como debe ser. Por eso para ya un caso diferente por decir que vamos a decir va a salir un hamburgesa nueva, entonces llaman a la persona, va a salir mañana una hamburguesa nueva, hay que quitar eso, vamos a poner esto aquí, entonces es cuando nos trae un traductor. En ese caso, no, porque aunque uno habla espanol, nosotros no hablamos inglés, pero ya en situaciones especiales, digamos, ya de las personas ahi que hablan ingles y espanol, nos dicen. Y ya, con la poquito que yo se, agarró la clave ahí.

L: Ya pregunte todas mis preguntas, pero si quiere añadir algo más, sobre cualquier cosa, se puede.

G: No creo

L: Como una historia?

G: Como que historia? Quiere que le cuente?

$\mathrm{L}$ : Si bueno! Una historia de nose, algo que paso que era divertido, o frustrante, o en que aprendió algo 
G: Algo divertido.... Las personas ahí en el trabajo esté como yo no se ingles, cuando me pongo a leer la computadora, y va a salir una hamburguesa nueva, me pongo a ver primero la clave, como va a salir, porque en la computadora que toma órdenes, aparece una clave diferente o con letras más largas, y ya en la computadora de la cocina, las claves son más reducidas, abreviadas, entonces me tengo que aprender las abreviaturas más pronto para que ya cuando sale la hamburguesa, yo ya les diga a las señoras "oh esto quiere decir este" L: Entonces en la cocina, a veces funciona como la maestra de com funcionan las cosas para los empleados mas nuevos?

G: (laughs) Si, por ejemplo ayer, llegó una caja que ahi trae el libro de la nueva hamburguesa.

L: Viene con un libro?

G: Si cuando va a salir una hamburguesa les mandan a los managers un librito de lo que va a salir nuevo, y ya yo veo ahí, ya estoy mirando que va a salir "oh va a salir un hamburguesa que lleva cebolla, cebolla frita, o que lleva diferente pan"... y ya les digo "oh va a salir una nueva hamburguesa," yo me voy adelantando a ver el libro para que ya vaya pensando cómo se v a hacer para que no se me dificulta cuando ya sale la comida a la venta, yo ya aprendi a hacerlo. Me gusta leer el no leer porque no se ingles pero si mirar este como se va a ir haciendo cada cosa, porque ahí te dice cuantas veces te vas a poner mantequilla, o si lleva sal, cuantas veces apretas al salero, una o dos veces de sal, todo eso uno tiene que aprender.

$\mathrm{L}$ : Si, porque hacen la diferencia entre una hamburguesa y otra.

G: El desayuno es diferente y el lunche es diferente. $Y$ muchos personas por eso se les dificulta aprender una porque no saben inglés y otra porque es mucho restaurantes de... no se Burger King. Wendy's, o Taco Bell, no se como seria el menu, pero McDonalds tiene mucha variedad.

L: Cada cuantos dias o meses sale una nueva hamburguesa?

G: Hay hamburguesas que han permanecido... uff... de siempre. Pero hay hamburguesas que vienen de temporada, por ejemplo en verano vienen unas bebidas diferentes, y en invierno son otras bebidas diferentes. Y también en la comida hay ensaladas en el invierno son diferentes, y en el verano otras ensaladas diferentes. $Y$ las hamburguesas igual. Hay hamburguesas que han permanecido y hamburguesas que vienen por tiempo limitado nada más. Y no se porque, pero vamos a decir dos meses, y apenas estas aprendiendo la clave cuando ya dice "oye mañana esto se va"

$\mathrm{L}$ : Tal vez porque los clientes les gustan unas recetas de hamburguesas más que otras? G: No se realmente porque, pero quitan eso, y ya te dicen ya va a venir otra hamburguesa nueva, por eso es que le digo yo que luego yo estoy mirando el libro... porque ya tenemos que saber cómo lo vamos a cocinar

L: Y si no, puede ser estresante

G: Si, si porque no sabes si como hay le van a chequear la temperatura cuando ya está cocinado, y le chequen la temperatura y si no dio la temperatura es que no lo pusimos correctamente. Y si ha pasado, ehh?!

L: Pero saben y lo hacen otra vez para aprender? 
G: Si, porque asi ya te das cuenta cuantos minutos era, o no estaba programada la parrilla, y le pusiste equivocado, si nos pasa muchos veces.

L: Hay un tiempo fijo en que tienen que cocinar el orden?

G: Sí, porque cuando sale tu tienes que tener un headset para que cuando están tomando el orden, ya vas adelantando ya estás oyendo por eso es bueno aprenderse la que está ahí iniciando ese es mas para la que está iniciando. Ehh, es bueno aprenderse los números porque si el cliente dice "quiero un numero 2" y tu ya sabes cual es el número dos, entonces ya pones el pan, ah hah, y la que está en la parrilla tiene que estar este viendo también que es lo que va a ir cocinando.

L: Que es el limite de tiempo para hacer cada orden?

G: Ehh, no me acuerdo.

L: Ah entonces no es muy estresante porque tienen el tiempo necesario?

G: Más o menos, si. Pero tampoco podemos tardar mucho, si toma una orden ahí en la ventanilla uno, cuando llega al ventanilla dos su comida ya tiene que estar ahí.

L: Wow. En el coche?

G: Si, cuando están en la coche. Porque si no esta ahi, los tienen que mandar a parquear, y ahi es donde pierde uno más tiempo, esto no le conviene ellos ni le conviene a nosotros, porque hay que salir a dejar la orden.

L: Ahh, entonces más fácil para ustedes si ya estan los órdenes.

G: Si, por eso cada quien dicen oh cuando está muy ocupado o ella es buena para la parrilla, que se quede en la parrilla, y ella es buena par'alla, que se quede tomando ordenes, asi cada quien tiene su especialidad.

G: La hora de lunche es entre 11-1, es la hora que ahi si esta lleno con todo que lo te da.

L: Entonces cuando puede comer su almuerzo usted?

G: Yo, el almuerzo me lo dan a los 9 ya tomo mi almuerzo

L: Entonce después pasa 9-3 sin comida?

G: No, no, después ya nos dan, si trabajas 8 horas, te dan media hora de lunche, y dos breaks de 10 minutos.

L: Cortos!

G: Si, por eso de 7-9, de 9-9:30, ya tomas tu lunch. De 11:30 mas o menos te dan tus 10 minutes, y ya los otros 10 minutos te lo dan a las 1, 1:15.

L: Um antes que empiece la grabadora, creo que dijo algo usted sobre los rols de trabajo, no se si recuerda...

G: Si, la gente hispana regularmente que sabemos ingles estan trabajando en la cocina, o limpiando las mesas, o se pone a barrer, o a lavar los trastes, es ya cuando vas aprendiendo poco a poco ya vas esté haciendo tu poniendote a cocinar la carne es lo primero que empezamos a trabajar es ese, a cocinar la carne, y ya poco a poco vas aprendiendo a leer las pantallas de la computadora, y ya es cuando ya vas aprendiendo el nombre de cada hamburguesa, y como sale la clave de las hamburguesas, entonces es cuando ya te estas menos tiempo en la parrilla, ya pasas ahi.

L: Muy bien, y otra persona llena la posición?

G: Y si, pero regularmente como cuando ya sabes en toda las posiciones en la cocina, entonces ya nos ayudamos un rato esta una, y al rato está la otra, solo si hay una persona 
que no puede trabajar en la... porque si hay personas que no les gusta trabajar en la... leyendo la computadora para hacer las hamburguesas

L: Porque?

G: Porque como está ocupado, dice que se pone nerviosa de ver tanta orden, entonces en este momento la persona siempre se queda en la parrilla para que nosotros hagamos mas rapida la comida.

L: Tiene sentido.

G: Y ya nosotros las que estamos ahi tratamos de aprendernos por eso tratamos de aprender la más rapido que se puede las claves de las hamburguesas, y que lleva cada hamburguesa, para que así no se nos dificulte a ninguna de nosotros cuando estamos trabajando y todo nos ayudemos. Porque si no te aprendes la clave se dificulta, pero aunque no sepamos inglés, aprendemos rápido a leer eso "oh eso quiere decir lechuga grande, o ese quiere decir lechuga picada, o eso quiere decir cebolla chiquita..." hay dos tipos de cebolla: frita, asada, a la parrilla, entonces ahí aparece a clave... son claves que nosotros tenemos que aprender, y que los aprendemos para que sepamos que lleva cada hamburguesa.

L: Si pudiera aprender hoy una cosa de inglés que tiene que ver con el trabajo, que sería?

G: La cosa que me gustaria aprender es leer bien las computadoras para tomar órdenes.

L: Mmmhmm,

G: Sí porque es diferente la pantalla o el sistema, no se como se diga, de la computadora que está tomando órdenes, es diferente al sistema que sale a nosotros con las claves.

L: Es más complicada la computadora?

G: Si, porque ahi viene... hay que saber manejar todo eso de las bebidas, y de manejar este... como cuando quiere algo extra como...

$\mathrm{L}:$ Y esto tiene que ver con el vocabulario que tiene la computadora, o la tecnología de la computadora? O los dos?

G: Yo pienso que el idioma, porque ya una vez sabes el idioma, ya si sabes leerlo, pues lo lees. Porque esta computadora no mas aprietas los botones. Muchas me han dicho asi se asi, pero yo me da miedo tambien, con el dinero. Yo me da miedo porque también como es mucho se vende mucho, hay mucho dinero, es mucha este clientela, y hay que estar como bien concentrado para dar bien el cambio, porque cuando hacen su corte de caja cada dos horas creo, ellos sacan todo su... y ahí si alguna caja salió corta, te dicen que salio corta una caja.

L: OK.

G: Ese tambien es estresante.

L: Pero el acto de hablar con los clientes no es tan estresante?

G: No.

L: Muy bien! Yo creo que con un poco mas de ingles, ya puede hacer el puesto de manager, no?

G: Pues, a lo mejor, si!

L: Pues, muchas gracias por hablar conmigo

G: No, pues no se si salio bien

L: Si! Creo que si. Ahora lo escuchamos. 


\section{Rosa's Interview Transcription}

L: Para empezar, voy a usar un nombre falso cuando me refiero a usted en mi proyecto, entonces qué nombre le gustaría que usaría?

R: Rosa.

L: Bueno. De dónde es usted?

R: De Michoacan.

L: Ahh bueno. Y cuáles idiomas habla?

R: Espanol

L: Ahora voy a hacerle a usted unas preguntas sobre su trabajo en McDonalds, y no se si ha trabajado en un restaurante diferente antes de McDonalds, pero si este es el caso, si quiere hablar sobre la experiencia de cualquier lugar de trabajo que sea un restaurante de comida rápida esta bien. Entonces, puede contarme la historia de cómo llegó a trabajar en McDonalds?

R: Ahh como yo empecé pues por una persona como amiga mía trabajaba en el restaurante, ella fue la que [helped get me the job there] despues, como la persona nos hizo una entrevista, esto fue muy difícil porque no hablamos el idioma. Entonces con tal de [something about the restaurant needing workers?] nos dieron trabajo. Eso fue la forma de como entre yo, ahh hah.

L: Muy bien! Y cuánto tiempo lleva usted trabajando en McDonalds?

R: Llevo 11 años trabajando para McDonalds.

L: Ahh wow bastante! Y cuando empezó en qué posición entró?

R: En la cocina.

L: Ok, y por cuánto tiempo hizo este rol de trabajo en la cocina?

R: Por unos 8 anos, 9 anos.

$L: O K$, entonces hace como 2 anos que le ofrecieron el rol de manager?

R: Ahh, un ano y medio.

L: Muy bien! Felicitaciones!

R: Gracias.

L: Le gusta las nuevas responsabilidades de ser manager?

R: Sí me gusta, pero para mi como no hablo perfectamente el idioma, se me hace difícil.

L: Si. Me imagino. Y cómo se sintió usted cuando empezó como manager?

R: Pues como todas las personas que trabajamos en la cocina hablan espanol, por eso me siento ajusto. Pero cuando estoy con mi supervisor o con mi store manager, para mi es muy difícil porque no puedo tener un diálogo. Y yo quisiera hacer más, pero es imposible porque no puedo hablar en inglés.

L: Entonces cómo manejan eso? Hay gente que hablan ingles y espanol y que traduzcan?

R: Algunos veces si, casi la mayoría de las cosas como es lo mismo las entiendo, por ejemplo umm yo tengo una... me refiero a otro manager que habla en inglés y ella me entiende lo que yo estoy diciendo por decir Sandra fue a su break, cuando regresa Sandra va a tomar Consuelo, etc. Con los pocas palabras que uso casi diario. 
L: Si si, por la repetición ya sabe lo que están diciendo. Entonces con el rol, siente satisfecha usted con las posición en McDonalds? O quisiera lograr tener un posición diferente?

R: Pues para mi seria mejor que en una posición diferente, como en la cocina, porque no tienes que tener diálogo con los clientes, no tienes que tener mas dialogo con otras personas, porque es muy frustrante.

L: Ahh ok. Y entonces está pensando en cambiar otra vez a trabajar en la cocina?

R: Si.

L: Si? Ahh ok. Y umm cómo va a hacer su decisión?

R: Ahh, yo ya hable con mi store manager y ella pues, dice que estoy haciendo bien, que no necesito cambiar, pero yo no me siento ajusto en este puesto.

L: Ahh ok, si si si. Y siente como que hay, no se, unos recursos para ayudar?

R: Si, nosotros de hecho hemos tenido clases en ingles, y todo con referencia a McDonalds.

L: Ahhhh he escuchado sobre ese programa, creo que se llama English Under the Arches?

Es eso?

R: Ya, ahh hah.

L: OK, muy bien. Creo que usted eres la primera persona que he conocido que sabe algo de ese programa, entonces me interesa mucho en su experiencia.

R: Sí. Nos dan clases, para como por decir este hablar cuando una... es todo referente a McDonalds, por ejemplo si un empleado llega, no tienes una comida, como puede decirle "ok, can you put the number one..." puras palabras que nosotros podemos usar en frases cortas, lo que usamos diariamente.

L: Ahh ok. Y ellos les pagan, no? Para hacer esas clases? Como que no tienen que faltar sus horas?

R: Sí, mmm hmm. Nos pagan las horas, si nosotros tenemos dos horas de clases en el schedule, nos ponen dos horas y son pagadas.

L: Cuantos horas por semana mas o menos?

R: Son 6. Mas un dia al mes 5 horas, emm en la oficina y el otro es teléfono, 6 ... dos horas, tres días.

L: Entonces por semana en total?

R: 6. Por semana, por un mes son 24 .

L: Hace cuando que está tomando clases?

R: Acabo de tomar, acabo de terminar en diciembre, no se cuando va a empezar de nuevo, pero ya fueron dos veces que participamos en la clase.

L: Ahh ok, ok. Y como siente después de terminar el programa?

R: Sí he aprendido un poco más, como por ejemplo hay cosas que yo no entendía que ahora ya entiendo un poco mas, y ya tengo mas confianza pero aun si todavia se te puede decir que tenía el $5 \%$, avance $25 \%$, pero todavía me falta un $70 \%$ para estar en...

L: Muy bien! Pero esto es buenisimo! Mucho trabajo, no?

R: Y si.

L: Wow. Um, entonces las clases van a arrancar de nuevo en unas semanas o que?

R: No, no nos han comentado nada, no nos han dicho nada, pues me imagino que ellos viendo la demanda de que hay personas que son buenos como para ser managers pero que no hablan 
inglés, como yo posiblemente, pues hagan más clases porque el dueño tiene muchos

McDonalds aquí en Vancouver, y somos muchos Latinos que trabajamos.

L: Cuantos más o menos estaban en la clase con usted?

R: Ibamos como unos 15, 16 [personas]

L: Ah wow! Bastante. Pero de varios McDonalds?

R: De varios restaurantes pero del mismo dueño.

$L:$ Muy bien. Ahora voy a hacerle a usted unas preguntas sobre los idiomas que usa en su trabajo. Entonces, pensando en su dia, me puede contar sobre un dia normal, como que es la primera cosa que pasa, etc., porque quiero saber como cuales cosas están pasando en ingles y cuales en espanol.

R: Pues en mi restaurante, casi la mayoria habla espanol. Entonces, es... para mi es cuando yo trabajo con las personas que hablan espanol, para mi es facil.

L: Facil.

R: Dirigirme hacia ellos. Como acabo de decir, las personas que hablan en ingles para mi se me hace dificil porque si yo tengo que decir a uno "ahh puedes quedar más tiempo" se me hace un poquito más complicado porque o con frases muy cortos por ejemplo, "more" posiblemente ellos me entienda, entonces eso es lo que para mi... o por ejemplo puede decir "o que buena hamburguesa" o "que buen trabajo haces" a una persona que habla inglés, que son, casi somos mitad o mitad, entonces en el McDonalds si divide que cuando uno está, dice corriendo, the front floor, es cuando tu tienes las responsabilidades de todos los empleados. Por ejemplo, de nosotros nos piden muchas cosas que nuestros tiempos deben estar bajos, que nuestros [indecipherable] deben estar bajos, nosotros tenemos que ver en qué lado se necesita ayuda y entonces para que tu puedas motivar a un empleado necesitas, yo aveces tengo las palabras pero no las puedo a decir en inglés.

L: Si si a mi me pasa lo mismo en espanol, muchas veces.

R: Entonces, eso es lo que pasa.

L: Si. Entonces, la mayoría de las cosas que tiene que ver con las responsabilidades de manager pasan en inglés? Que porcentajes más o menos?

R: Es un, se puede decir que es un $65 \%$ en inglés, y un $35 \%$ en espanol.

L: Ah ok, genial. Muy bien. Y hay algo o sea cuales cosas específicas le gustaría poder hacer en ingles?

R: Como, lo que acabo de decir como poder aprender mas a como coordinar la gente, como decir "patrón, eso no se tiene que hacer, necesitamos más gente, necesitamos más esto, mas cosas, mas esto," o sea para mejor funcionamiento de la tienda y de los empleados.

$L$ : Eso tiene que ver mucho con la comunicación entre usted y su manager?

R: Si, mi supervisor. Son mas arriba que yo.

$L:$ Pero con lo que tiene que comunicar entre usted y la gente quienes trabajan en la cocina, eso va mas fácil?

R: Eso no es tanto, porque casi la mayoria habla espanol. Son dos personas [que hablan inglés] pero casi por la regular con el poco que he aprendido un poco más pues me hace mas facil. "Daniel, you don't need to take the hands, you need to take the tongs," cuando están haciendo un, por decir, no tenemos que agarrar el chicken con la mano. Tenemos que usar una pinza. Entonces tenemos que corregir a ese empleado que habla inglés, entonces a por 
ejemplo a veces tengo que decir "Daniel, no puedes hacer eso, tienes que usar tus pinzas para agarrar una chicken." O por ejemplo, vino un empleado que no trajo su uniforme completa, se me hace dificil "ok yuri, no traes tu pantalón, te voy a mandar a tu casa." $O$ sea, cosas de esas se me hace muy difícil.

L: Como cuando tiene que corregir algo, es difícil. Si. Y en la clase de inglés, los profesores tenían ejercicios para enseñar este tipo de interacción?

R: Si.

L: Pero todavía falta un poquito para sentirse cómoda en las situaciones así?

R: Sí, demasiado todavía. Porque cuando tu no sabes una cosa, es como cuando los niños empiezan a caminar. Tienes que repetir caminar y caminar para que puedas caminar. Lo mismo pasa en uno, porque no nos estamos estudiando como si fuera escuela, son dos horas tres días por semana, pero despues vas a tu trabajo, y no hay tiempo suficiente.

L: Es demasiado rápido, entonces? Porque no hay tiempo para absorber el nuevo conocimiento?f

R: Ahh hah. Porque no practicamos constantemente.

L: Hmmm. No se si usted habla mucho con los clientes, pero puede contarme sobre la última vez que hablo con un cliente?

R: La ultima vez que hable con un cliente uno estaba pidiendo un sándwich, tenemos un ham cheese muffin, y un [another kind of muffin]. Entonces, yo lo dije "with egg? With not egg?" Y el no me entendía porque la frase posiblemente no es lo mismo cuando tu hablas perfectamente inglés, lo dices rapido, y cuando no hablas así, el cliente me dijo "no te entiendo, no se que estas diciendo" y se fue. Y eso es cuando uno se siente frustrada.

$L: Y$ al final no compro su sandwich?

R: No compro su sandwich, porque... pero hay personas que sí porque el dialogo que estan usando son lo mismo, "I want number one with a biscuit and etc." es lo mismo que siempre, entonces eso entiendo perfectamente.

L: Piensa usted que la habilidad de ser bilingual es importante para los empleados de la cocina?

R: Sí, porque hay veces que por decir los de la cocina no habla, entonces el store manager y la supervisora [quienes no hablan español], entonces vienen a mi y dicen "Sara no hace los sandwich suficientemente rápidos" entonces le dije a Sara "necesito que hagas más rápido las sandwiches" en inglés, y Sara se queda... pues [silent] entonces el store manager y la supervisora me dicen "pues, necesito que hablas con Sara y decirle que hagan más rápido las sandwiches" entonces voy, y le digo a Sara "Sara, dicen que ella necesita que hagas más rápido los sandwiches." Entonces, si uno aprender mas, fuera [less of a waste of time] porque después de todo [ the back and forth and misunderstandings and translating] ya son quince minutos [gastados].

L: Mucho. Esos fueron todos mis preguntas escritas, pero no se si viene a la mente algo más para mencionar sobre su experiencia con referencia al idioma?

R: Pues que si, les hago difícil porque estamos en un país donde se habla, la mayoría es inglés, entonces hay personas que no piensan lo mismo que otras, y el simple hecho de que tu hablas y no te entiendan, es difícil y a veces te frustras porque no es el mismo conocimiento. 
L: Y eso tiene que ver con el tratamiento en el trabajo?

R: Hmm mmm.

L: Ha experimentado situaciones en que ellos no te tratan bien por la diferencia del idioma?

R: No.

L: Ok, muy bien. Para clarificar algo, el programa English Under the Arches es solo para gente quienes ya trabajan como manager?

R: Si. Para managers.

$L:$ Ah ok, entonces no hay un recurso similar para los de la cocina que quieren aprender inglés?

R: No. Eso es solamente para managers, a lo mejor la demanda es más para managers porque es más de supervisor, todo que pasa en un McDonalds tenemos reuniones pero a veces no entiendo lo que están diciendo para decir "ok, este mes, hubo faltante de " porque la mayoría de los managers hablan inglés, hay veces en que uno quiere hablar para expresar "ok si hiciéramos esto, a lo mejor funcionaria mejor" si tomaran más en cuenta los empleados, funcionaria mejor. Pero personalmente no lo puede decir.

L: Tiene usted como una idea o una sugerencia de como mejorar este problema?

R: Pues es que como pues para mi seria que... es que... como lo explico... a lo mejor si estos personas quieren aprender, pero como ya somos, no tenemos el tiempo suficiente por decir - que ya estamos cansados despues de trabajar, porque pues aqui la unica parte que se que hay clases de inglés es en el Clark College, pero a veces, por ejemplo, personalmente, yo llego cansada, tengo que hacer esto, esto, y esto, ya no me da tiempo suficiente, y ya uno no quiere agarrar tiempo para ir a estudiar.

$\mathrm{L}: \mathrm{Si}$, siempre el dinero y el tiempo son las barreras más difíciles alcanzar. Alguna vez ha ido usted a las clases en Clark College? O en otro lugar?

$R$ : Anteriormente yo asiste a la clase en St. Johns, cuando yo vine aquí a los estados unidos, iba a la escuela primaria en St. Johns y ahí nos daban clases de inglés.

L: Si si. Bueno, muy bien, muchas gracias por hablar conmigo, y contarme un poco sobre su experiencia, me ayuda mucho en mi proyecto. Tal vez, no se, luego hoy voy a pensar en otra pregunta, pero si esto me pasa esta bien si le envio un mensaje de texto si quedo con unas preguntitas mas?

R: Si, esta bien.

L: Muchas gracias! 


\section{A Note on Coding}

During the process of writing the analysis section, I realized my first research question, "What are the experiences of native Spanish-speakers in fast food in relation to language?" is too broad, and points to a multitude of answers that address a multitude of factors. Therefore, I instead folded it into the other three research questions during my data organization and analyzation process, and added the section regarding restaurant context to provide necessary contextual information that is not a direct response to one of my research questions but is highly related to the research topics. In the end, this made the other themes stronger and more specific. Lastly, I removed this original research question from my coding of the transcripts, since I did not analyze my data through the lense of this overly broad research question. 
The topics of ethnicity and race can be intrinsically tied to language in ways that are beyond the scope of this research. It can be challenging to separate these parts of a person's identity because language is often tied to culture, place of origin, ancestry, etc. While I did explicitly interview native Spanish speakers with the specified hope of gaining perspective into their experience because they comprise a large amount of the Portland fast-food workforce, I did not ask questions about how they have experienced their workplace through the lense of their appearance (skin color, height, etc); rather, all of my questions were centered around their language use and how this affects their experience navigating the world. However, the topic of race came up in my interview with one participant and I want to let her voice be heard because her experience matters. The following interview excerpt is lengthy but worth reading. To provide context, we were discussing her supervisor who had been behaving unethically and was recently fired.

L: "¿[C]omo fue hablar con ella?"

[L: How was it to talk with her?]

C: "No, casi este no hablaba yo mucho con ella, ahh hah."

[C: No, I almost didn't talk to her at all, ahh hah.]

L: "Si. ¿Y ella hablo español tambien?"

[L: Yes. And did she also speak Spanish?]

C: "No. No ella no hable español."

[C: No, she doesn't speak Spanish.]

L: “Ahh, ok. ¿Y qué piensa sobre eso, usted?”

[L: Ahh, ok. And what do you think about that?] 
C: "Que pienso? Pues, pienso siempre que es a veces pienso que también mucho racismo."

[C: What do I think? Well, I always think that sometimes I think that also it's a lot of racism.]

L: "Si."

[L: Yes.]

C: "Entre ellos para nosotros, más con los hispanos [...] Porque ella también [...] decidía que por ejemplo, que si ibas a faltar un mes antes que se le diera"

[C: Within them directed towards us, more with the Hispanics [...] Because she also [...] decided that, for example, if you were going to miss [a day of work] you would need to let her know a month ahead of time to get the time off.]

L: "Un mes es mucho!"

[L: A month is a lot!]

$\mathrm{C}$ : "Si, entonces $[\ldots]$ nosotros dijimos a la otra muchacha que hablaba ingles y espanol que nos dijera que a veces para hacer una cita no es posible saber un mes antes la fecha, a veces menos. También ella siempre decía “a mi, no me importa - si no quieren trabajar, pues, no pueden.” Entonces, siempre era eso. Pero le dijo a los que ella les caía bien, hay muchos muchachos tal vez porque son muchachos, no tienen la necesidad de que, pues un dia antes llaman, que no van a venir a trabajar, y no pasa nada.” [C: Yes, so we told the other woman [another manager] who spoke both Spanish and English that sometimes to make an appointment it is not possible to arrange it a month prior to the date, sometimes it is less. Also she always said "it doesn't matter to me - if 
you all doing want to work, don't work." So it was always like that. But like I said for those who got along with her, there are a lot of young guys and maybe it's just because they are young guys, but they don't have to [tell her a month in advance], they just call a day ahead of time that they aren't going to come in for work, and everything is fine.]

L: ¿Como? No entendi.

[L: What? I didn't understand.]

C: "Hay veces que en cómo los muchachos de high school por ejemplo no pueden venir a trabajar. Tal vez es porque ellos como que no tienen la necesidad de trabajar, ellos si con un dia antes o en la noche hablan que no van a ir o si entran, por ejemplo si entran a las 9 y a las 8 hablan que no van a ir a trabajar, pues esta bien.”

[C: There are times when the young guys who are in high school for example can't come in to work. Maybe it is because they don't have the necessity to work, but for them with just a day, or even just the night before they call and say they won't come in to work the next day, for example if their shift starts at 9 and they call at 8 to say they aren't coming to work, everything is fine.]

L: “¿Pero esto no puede pasar con las más grandes?”

[L: But this can't happen with the older employees?]

C: "Con las más grandes o con gente hispano, eso no puede pasar"

[C: With the older employees or the Hispanic people, this cannot happen.]

L: “Ahh! ¿Entonces los chicos no son hispanos?”

[L: Ahh so the boys aren't Hispanic?]

C: "No. No son hispanos." (Carla, lines 89-117) 


\section{[C: No, no they are not Hispanic.]}

Again while I was not originally planning on discussing the topic of racism and discrimination based on ethnicity, the topic came up naturally as it was something Carla wanted to talk about. In hindsight I wish I had asked more follow-up questions regarding this topic, but I did make a point of asking the other two participants if they had ever experienced any sort of differentiated treatment because of the language they speak and neither of them had any experiences to share on the matter.

Carla also mentioned an unsettling experience she had with a customer that made her uncomfortable and in which she actually pretended not to understand what he had said in English in order to escape the situation, which I find very interesting:

C: "Como hoy un cliente que llegó el fue que dijo que "como mira esta chaparrita de cocina..." "dice oy, yo pensé que la gente que trabajaba para estar ahi dice tenía que estar más alta!" (laughs)

[C: Like today a client who showed up, he said "look at this short kitchen worker woman..." he said "hey, hey I thought that the people that worked back there, in order to work there you had to be taller! (laughs)]

L: “¿Dijo esto a usted?!”

[L: He said that to you?!]

C: “A mi! Ah hah! Yo parece que no lo entendí, le digo "no se que quieres decir," y ya me fui. [...] Todo el mundo, altas o chaparritas, hacemos el mismo trabajo!" (Carla, lines 159-176) 


\section{[C: To me! Ah hah! I pretended like I didn't understand, I told him "I don't know what} you are saying," and I left. [...] Everyone, tall or short, we do the same work!]

It's difficult to say what motivations the customer had in saying this to Carla, but she clearly took offense to it, as it was a very unkind thing to say. While it is likely that the customer meant this as a joke, Carla felt indignant that she works hard every day, accomplishing each task handed to her regardless of her height and other characteristics, and that this man should make a point of how short she is. As she said, in her workplace tall and short people all do the same work. While this is not an explicit example of racism or discrimination because it involves no actual actions besides a misguided verbal remark, it does come across as a derogatory remark directed at someone in response to their appearance, especially when coming from someone she described as an older white english-speaking male. I don't know whether this same customer would have made that remark to a petite caucasian woman, or a short male teenager working at the restaurant, but for Carla she found this an offensive thing to say and de-escalated the situation by pretending to not understand the customer and returning to her work in the kitchen. This situation does demonstrate the inherent power that comes with knowing and understanding language, who is speaking the language, how they are using it to assert their power, etc. The nuances in power dynamic visible in this situation (English speaker to Spanish speaker, more specifically white man to brown woman, customer to employee) could be possible factors in how Carla's confidence is affected by the context in which she uses English. In this one specific interaction, her ability to pretend she didn't speak enough English to understand what the customer said aided her in not having to further engage with his hurtful remark, giving her power in the situation. I am concerned about is the association of power dynamics between the 
participants and the context in which they are required to speak English; at work, they are required to speak it with two groups of people: supervisors / managers, and customers.

Traditionally in this culture, we expect employees in the service industry to operate under two assumptions: 1) the customer is always right, and 2) respect and comply with the rules and wishes of authority figures. Therefore, because of these power dynamics in which the service worker is often expected to behave as the lesser power, this can play a large role in affecting the speaker's confidence when they are learning an L2. 


\title{
Appendix F: IRB Approval Letter
}

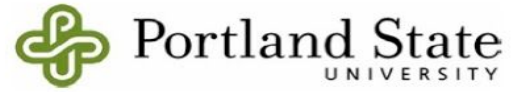

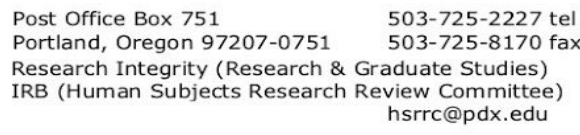 \\ Date: December 27, 2018 \\ To: Kathryn Harris / Livia Lichtenstein-Hershman; Applied LInguistics \\ From: Jack Barbera, IRB Chair

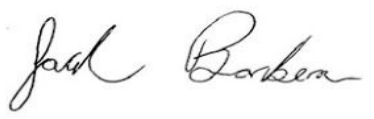 \\ Re: $\quad$ IRB approval for your protocol \# 184880, entitled: "A present-situation analysis and needs assessment of native \\ Spanish speakers in the Portland fast-food industry: A study of their employment journeys \& job-related linguistic \\ needs."
}

Approval-Expiration: December 27, 2018 - December 26, 2019

Notice of IRB Review and Approval - Initial Review

Expedited Review Categories 6, 7; as per Title 45 CFR Part 46

In accordance with your request, the PSU Institutional Review Board (Human Subjects Research Review Committee) has reviewed and approved the project referenced above for compliance with PSU policies and DHHS regulations covering the protection of human subjects. The IRB is satisfied that your provisions for protecting the rights and welfare of all subjects participating in the research are adequate. Please note the following requirements:

Approval: You are approved to conduct this research study only during the period of approval cited above, and the research must be conducted according to the plans and protocol submitted (approved copy enclosed).

Consent: You must use IRB-approved consent materials with study participants. Signed consent is waived; a written consent statement is required.

Changes to Protocol: Any changes in the proposed study, whether to procedures, survey instruments, consent forms or cover letters, must be outlined and submitted to the IRB immediately. The proposed changes cannot be implemented before they have been reviewed and approved by the IRB.

Continuing Review: This approval will expire on 12/26/2019. It is the investigator's responsibility to ensure that a Continuing Review Report is submitted to the IRB two months before the expiration date, and that approval of the study is kept current. The Continuing Review Report is available on the Research Integrity website.

Adverse Reactions and/or Unanticipated Problems: If any adverse reactions or unanticipated problems occur as a result of this study, you are required to notify the Research Integrity within 5 days of the event. If the issue is serious, approval may be withdrawn pending an investigation by the IRB.

Completion of Study: Please notify the IRB as soon as your research has been completed. Study records, including protocols and signed consent forms for each participant, must be kept by the investigator in a secure location for three years following completion of the study, or five years following completion if the study is funded (or per any requirements specified by the project's funding agency).

If you have questions or concerns, please contact the Research Integrity office in Research \& Graduate Studies at hsrrc@pdx.edu or (503) 725-2227. 